\title{
YEARS OF PARTNERSHIP WITH KARNATAKA
}

EVOLVING MODEL FOR SUSTAINABLE URBAN WATER SERVICE DELIVERY 



\section{YEARS OF PARTNERSHIP WITH KARNATAKA EVOLVING MODEL FOR SUSTAINABLE URBAN WATER SERVICE DELIVERY}

Akira Matsunaga, Saugata Dasgupta, and Sourav Majumder

DECEMBER 2020 
(C) 2020 Asian Development Bank 6 ADB Avenue, Mandaluyong City, 1550 Metro Manila, Philippines

Tel +632 8632 4444; Fax +63286362444

www.adb.org

Some rights reserved. Published in 2020.

ISBN 978-92-9262-559-7 (print); 978-92-9262-560-3 (electronic); 978-92-9262-561-0 (ebook)

Publication Stock No. ARM200372-2

DOI: http://dx.doi.org/10.22617/ARM200372-2

The views expressed in this publication are those of the authors and do not necessarily reflect the views and policies of the Asian Development Bank (ADB) or its Board of Governors or the governments they represent.

ADB does not guarantee the accuracy of the data included in this publication and accepts no responsibility for any consequence of their use. The mention of specific companies or products of manufacturers does not imply that they are endorsed or recommended by ADB in preference to others of a similar nature that are not mentioned.

By making any designation of or reference to a particular territory or geographic area, or by using the term "country" in this document, $A D B$ does not intend to make any judgments as to the legal or other status of any territory or area.

This work is available under the Creative Commons Attribution 3.0 IGO license (CC BY 3.0 IGO)

https://creativecommons.org/licenses/by/3.0/igo/. By using the content of this publication, you agree to be bound by the terms of this license. For attribution, translations, adaptations, and permissions, please read the provisions and terms of use at https://www.adb.org/terms-use\#openaccess.

This CC license does not apply to non-ADB copyright materials in this publication. If the material is attributed to another source, please contact the copyright owner or publisher of that source for permission to reproduce it. $\mathrm{ADB}$ cannot be held liable for any claims that arise as a result of your use of the material.

Please contact pubsmarketing@adb.org if you have questions or comments with respect to content, or if you wish to obtain copyright permission for your intended use that does not fall within these terms, or for permission to use the ADB logo.

Corrigenda to ADB publications may be found at http://www.adb.org/publications/corrigenda.

Note:

In this publication, “\$” refers to the United States dollar.

ADB recognizes "Korea" as the Republic of Korea.

Cover design by Michael Cortes.

On the cover: A woman whose smile indicates that she has a healthy and dignified life, and a group of schoolchildren joyfully sharing and drinking water directly from the tap (photos by Karnataka Urban Infrastructure Development and Finance Corporation). 


\section{Contents}

TABLES, FIGURES, AND BOXES

V

FOREWORD

vi

MANAGING DIRECTOR'S MESSAGE

vii

ACKNOWLEDGMENTS

viii

ABBREVIATIONS

ix

SUMMARY

$\mathbf{x}$

I INTRODUCTION TO PARTNERSHIP

A. Overview of the Karnataka Urban Infrastructure Development Project $\quad 1$

B. Lessons from the Karnataka Urban Infrastructure Development Project 2

II FIRMING UP PARTNERSHIP 3

A. Overview of the Karnataka Urban Development and Coastal Environmental 3 Management Project

Key Feature: House Service Connections 4

Key Feature: Community Awareness and Participation Program 4

- Key Feature: Public-Private Partnership for the Mangalore Sewage Treatment Plant 5

- Key Feature: Municipal Reform Program and a Model for India 5

B. Lessons from the Karnataka Urban Development and Coastal Environmental $\quad 7$ Management Project

III INNOVATION THROUGH PARTNERSHIP 9

A. Overview of the North Karnataka Urban Sector Investment Program 9

Key Feature: Ilkal, the First Indian City to Achieve 24/7 Water Supply 10

Key Feature: Community Development 12

B. Lessons from the North Karnataka Urban Sector Investment Program 13 
IV PARTNERSHIP FOR TRANSFORMATION

A. Overview of the Karnataka Integrated Urban Water Management Investment Program

B. Infrastructure Development

C. Institutional Transformation

Key Feature: Institutional Transformation with State Policy Reform

Key Feature: Institutional Transformation Implemented with Urban Local Body Incentive Funds

Key Feature: Institutional Transformation through Information Technology Module Development to Implement Urban Local Body Reforms

D. The Karnataka Integrated Urban Water Management Investment Program Model

V NEW CHALLENGES IN URBAN KARNATAKA

A. Climate Change and Water Conservation to Counter Future Drought

B. Business Process Reengineering to Meet Growing Demand for Urban Services 


\section{Tables, Figures, and Boxes}

\section{TABLES}

1 Outcome of the Karnataka Urban Development and Coastal Environmental Management Project (Water Supply)

2 Impact of the Municipal Reform Program under the Karnataka Urban Development and Coastal Environmental Management Project

3 Modality of a Performance-Based Construct and Operate Contract

4 Impact of 24/7 Water Supply Project in Ilkal Town under the North Karnataka Urban Sector Investment Program

5 ADB Support to Infrastructure Development under Project 1 (Ongoing), Karnataka Integrated Urban Water Management Investment Program

6 ADB Support to Infrastructure Development under Project 2 (Ongoing), Karnataka Integrated Urban Water Management Investment Program

7 Activities of the Urban Local Body Incentive Funds Supported by the Information Technology Modules

\section{FIGURES}

1 How the Ilkal Model Evolved into the Karnataka Integrated Urban Water Management Investment Program Model

2 Virtuous Cycle of the Karnataka Integrated Urban Water Management Investment Program Model for Sustainable Water Services

\section{BOXES}

1 Major Features of the Public-Private Partnership with Mangalore Special Economic Zone

2 Water Service Charters and Water Safety Plans in Karnataka

3 Functionality of the Information Technology Modules 1 and 2 
$\square$ Foreword

KENICHI YOKOYAMA, Director General, South Asia Department, ADB

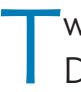
wenty-five years ago, in 1995, the first urban development intervention in India of the Asian Development Bank (ADB) commenced in the State of Karnataka, with the approval of the Karnataka Urban Infrastructure Development Project (KUIDP). I am delighted to see that the release of this publication reflects the accomplishments and learnings over this period, and how the joint endeavor of ADB and the State of Karnataka has continuously strengthened, as demonstrated by their consecutive successful interventions. Through the years, these interventions have evolved, with innovative project design supported by municipal reforms, first at the town level across the state, followed by the institutionalization of urban service delivery.

A time-bound delivery of services in the urban sector requires sustained commitment, planning, and concerted efforts; hence, the state decided to establish a dedicated institution. Karnataka Urban Infrastructure Development and Finance Corporation Limited (KUIDFC), which was established in 1993 during the processing of the KUIDP, has been the nodal agency and partner of ADB in urban infrastructure development. Implementing infrastructure works in congested urban spaces has numerous challenges that require multidimensional and multidisciplinary skills. KUIDFC has institutionalized the needed skills and capacity with perseverance and dedication toward the goal of delivering comprehensive urban development.

While there are milestones which are yet to be achieved, the experience of ADB and KUIDFC provides lessons for urban infrastructure planning, city governance, and robust service delivery mechanisms for other Indian states, South Asian countries, and beyond. The Ilkal model of continuous uninterrupted water supply across the town emphasizes on high-quality services for water projects, whereas the municipal reform program strengthens the governance and enhances the self-reliance of urban local bodies across the State of Karnataka.

With the evolving urban scenario in the State of Karnataka, KUIDFC's role has become more relevant to contribute toward integrated planning and resource mobilization for the urban local bodies. With its 25 years of experience in the development sector, KUIDFC can take the lead in structuring multisector development programs with resource mobilization from development partners and private sector entities, and in helping the government establish appropriate regulatory mechanisms for the sustainable and equitable delivery of urban services in the state. ADB is committed to continue supporting the State of Karnataka in its journey toward its development goals and becoming more service delivery oriented through citizen-centric planning and execution.

I sincerely appreciate the officials of the Department of Economic Affairs of the Government of India, as well as the officers and staff of the Government of Karnataka, particularly those from the urban development and municipal affairs department. I am also grateful to the managing director of KUIDFC and her team, for being at the helm of this successful journey and for their contribution to this publication. This publication also benefited from the valuable inputs of several individuals, including current and past project officers of ADB, current and past officials of KUIDFC, project beneficiaries, and other development partners supporting the KUIDFC. To all, thank you. 


\section{Managing Director's Message}

CHARULATHA SOMAL, Managing Director, KUIDFC

Tro he he publication of 25 Years of Partnership with Karnataka:

Evolving Model for Sustainable Urban Water Service Delivery tells of the commitment, support, and collaboration of our most valued partner, the Asian Development Bank (ADB). Since 1995, the partnership has supported four ADB-assisted projects in some 50 project towns and touched the lives of an estimated 4 million urban residents. To address emerging urban challenges, we have pioneered the development of core infrastructure and ushered in urban reform.

The partnership gave birth to many innovations, perhaps most notably the efficient use of treated wastewater and water conservation in

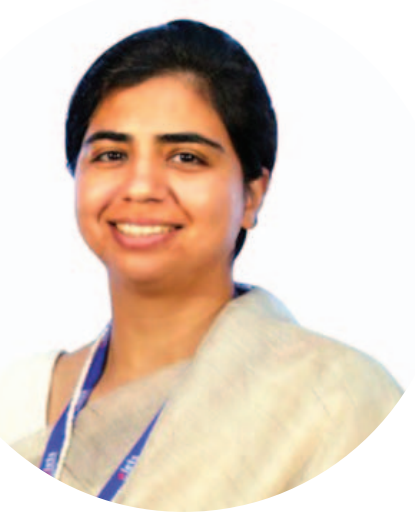
Mangaluru City through a public-private partnership with the Mangalore Special Economic Zone, and the achievement in Ilkal, a town in Bagalkot District, of 24/7 water supply-a first for an Indian municipality.

Water infrastructure investments created water treatment plants with a combined capacity of nearly 650 million liters per day, 9,000 kilometers of water pipelines, and other sewerage assets. The experience has transformed the Karnataka Urban Infrastructure Development and Finance Corporation (KUIDFC) into an expert specialist in water treatment and in various other areas of urban infrastructure.

Through KUIDFC, the Government of Karnataka received ADB support to pioneer municipal reform toward improving the sustainability of urban local bodies (ULBs). ADB continues to back ULB reform to ring-fence ULB water accounts, achieve $100 \%$ household metering, properly distribute and use treated wastewater, introduce information technology into billing, and establish functional customer service centers in project towns with 24/7 water supply. These measures will help ULBs avoid budget deficits, become more transparent, and provide better services. Reform programs in Karnataka may become a model for India.

Our deep-rooted partnership with ADB recently enabled us to react to the coronavirus pandemic by bringing out in May 2020 a timely standard operating procedure and a health and safety plan for all KUIDFC projects.

ADB experts furnished novel and thought-provoking comments during their periodic field visits, missions, discussions, and meetings. We in KUIDFC would like to express our sincere gratitude to them for their valuable advice throughout the projects, and to ADB for its financial support.

KUIDFC looks forward to extending its ADB partnership to new heights of innovation, to achieve the Sustainable Development Goals by 2030. We aim to build climate-resilient infrastructure in Karnataka for all of our people, now and in the future. 


\section{Acknowledgments}

This publication was written by Akira Matsunaga, senior urban development specialist of the Urban

Development and Water Division (SAUW), South Asia Department (SARD), Asian Development Bank (ADB); Saugata Dasgupta, project management specialist, Nepal Resident Mission, SARD; and Sourav Majumder, senior project officer (urban), India Resident Mission (INRM), SARD.

Preparation of this publication benefited from the guidance of, and insightful comments from, Kenichi Yokoyama, director general, SARD; Norio Saito, director, SAUW, SARD; Masayuki Tachiiri, regional director, Pacific Department; Coral Fernandez Illescas, principal water resources specialist, Sustainable Development and Climate Change Department; and ADB colleagues who participated in knowledge sharing session held in July 2020.

The authors are grateful for the constant and dedicated support of the following members of the ADB SARD book preparation team: Ashwin Hosur Viswanath, senior project officer (urban), INRM, SARD; Pramod Kumar, associate project officer (procurement), INRM, SARD; Edgardo Moises, associate project officer, SAUW, SARD; Jade Marie Dumaguing, associate project analyst, SAUW, SARD; and Donna Marie Melo, operations assistant, SAUW, SARD.

The authors would also like to express their sincere appreciation to the officials of the Economic Affairs Department of the Government of India, and those in the Government of Karnataka. Special mention goes to Charulata Somal, managing director of Karnataka Urban Infrastructure Development Finance Corporation, for her leadership in facilitating transformational reform in the delivery of sustainable urban services, and for her valuable contribution to this publication. 


\section{Abbreviations}

ADB Asian Development Bank

CAPP community awareness and participation program

DMA district-metered area

GIS geographic information system

IT information technology

IWRM integrated water resources management

KIUWMIP Karnataka Integrated Urban Water Management Investment Program

KUDCEMP Karnataka Urban Development and Coastal Environmental Management Project

KUIDFC Karnataka Urban Infrastructure Development and Finance Corporation Limited

KUIDP Karnataka Urban Infrastructure Development Project

MLD million liters per day

NGO nongovernment organization

NKUSIP North Karnataka Urban Sector Investment Program

NRW nonrevenue water

O\&M operation and maintenance

OBA Output-Based Assistance

PBCOC performance-based construct and operate contract

SEZ

special economic zone

SHG self-help group

UIF urban local body incentive fund

ULB urban local body

UWSS urban water supply and sanitation

WSP $\quad$ water service plan 


\section{Summary}

Background. This publication looks at 25 years of development partnership between the Asian Development Bank (ADB) and the Indian state of Karnataka and their joint endeavor to enable sustainable and inclusive urban development in the state. ADB support to the State of Karnataka started in 1995, with the approval of the Karnataka Urban Infrastructure Development Project, which was also the first ADB urban sector loan in India. Since then, ADB-supported programs have expanded across the state through three consecutive urban programs, reaching 43 towns in southern, northern, and coastal Karnataka. The programs have supported water supply, sewerage systems, solid waste management, stormwater drainage, urban roads, and slum development through community development and municipal reforms. This silver jubilee provides an occasion to look back on pioneering accomplishments in water services in Karnataka and explore the lessons that experience provide for urban sector interventions in South Asia.

Interactive partnership for improved interventions. The project interventions have evolved over time, reflecting lessons learned from previous projects and innovating new project design, scope, andto improve urban water services - operation and maintenance (O\&M) arrangements. The constructive partnership between ADB and the Government of Karnataka has been anchored upon the logical progression of ADB's investment projects, starting with sector analysis and capacity building through technical assistance. Subsequent policy dialogues identified the required investments and policy actions. Technical and institutional challenges in implementation and O\&M were jointly reviewed and corrective actions were taken. Lessons learned from past programs were shared during consultations held for designing the next interventions. Success of project-specific interventions have been scaled up and institutionalized to bring broader changes in subsequent phases.

Ilkal model-the 24/7 water supply. Water supply improvements are focused interventions in all ADB-funded programs to the State of Karnataka. ADB and Karnataka Urban Infrastructure Development Finance Corporation have worked together to introduce good water supply practices to local municipalities in the state, making Ilkal - a small town in a drought-prone area of North Karnataka - the first municipality in India to achieve 100\% water supply coverage all day, every day. The resulting "Ilkal model" has subsequently been widely scaled up in ADB-funded projects elsewhere in South Asia. This model features 24/7 water supply, 100\% coverage, service connections to individual houses, district-metered areas to reduce water losses, and a contract modality known as performance-based construct and operate contract (PBCOC). The PBCOC includes a long period of O\&M by a private operator after construction is completed.

KIUWMIP model-building a robust virtuous cycle in water services. The Karnataka Integrated Urban Water Management Investment Program (KIUWMIP) is a continuing effort to ensure sustainable water service delivery over the long term through institutional reform. In addition to state-level policy reform, the initiative is introducing innovative implementation mechanisms in project towns, such as a newly developed information technology module for dynamic asset management and dedicated funds to incentivize reform implementation. Building on the Ilkal model and the KIUWMIP model of enhanced 
intervention, subsequent efforts to develop a robust virtuous cycle for sustainable water service delivery strive to (i) build high-quality infrastructure that are able to provide $24 / 7$ water supply, with $100 \%$ coverage in direct connections to houses, less nonrevenue water, and asset management and operation monitoring technologies; (ii) improve water services, with incentives for operators, real-time monitoring of service delivery and operator performance, and incentives for water utility to implement reform actions;

(iii) conduct community awareness activities to improve people's understanding of project benefits; and (iv) provide adequate financial sources through lower costs and appropriate user charges, ultimately achieving full cost recovery of O\&M.

Key lessons. As ADB and the Government of Karnataka celebrate 25 years of partnership in 2020, the task of providing towns and cities in the State of Karnataka with modern water supply and sewerage remains half-done. Experience provides the following lessons for completing such task:

(i) Access to high-quality services must be an explicit target of water projects. Maximizing project impact to beneficiaries should be the top priority and the first round of a virtuous cycle for water services.

(ii) Well-defined project design and scope minimize implementation problems. During project preparation, capacity should be assessed to find the right balance between project complexity and implementation capacity.

(iii) Extensive community awareness programs are essential. Social components are as important as technical components to project sustainability, adding lift to the upward spiral.

(iv) Institutions matter. Continuing institutional transformation and business process reengineering of project interventions help realize sustainable water service delivery at larger scale.

(v) A virtuous cycle cannot be built in a day. The interventions have evolved over decades through constant interactions among stakeholders. Development partners should learn from past experiences, adopt a programmatic approach, and continue to reach out to beneficiary communities to ensure sustainable service delivery. 


\section{Asian Development Bank Support to Urban Karnataka}

\section{Basic Data}

- Loan amount

- Loan period

Number of project towns

Major project components

\section{Interactions for improving}

\section{program interventions}

\section{Water Supply}

People benefited with

improved potable water supply

- Total water treatment plant

capacity

notal length of piped network

\section{Water Supply}

Service Improvemen

24/7 water supply

$100 \%$ coverage

- Household connections

Performance-based

operator contract

- Municipal reform

\begin{tabular}{|l|}
\hline \multicolumn{1}{|c|}{1995 KUIDP } \\
\hline$\square 80$ million \\
$1995-2002$ \\
6 towns \\
water supply, sewerage systems, \\
solid waste management, \\
stormwater drainage, \\
urban roads, slum upgrade, \\
and industrial site development \\
\end{tabular}

$\rightarrow$ Sector analysis, project preparation and institutional building for KUIDFC

\begin{tabular}{l}
-0.9 million \\
$65 \mathrm{MLD}$ \\
$-300 \mathrm{~km}$ \\
\hline
\end{tabular}

Not targeted

- Not targeted

- Not designed

- Not designed

- Not designed

\section{KUDCEMP}

\$145 million

1999-2009

10 towns

water supply, sewerage systems, street and bridge improvements, coastal environmental

management, capacity building, community participation, and poverty reduction

\section{$\rightarrow$ Feedback from the KUIDP,} sector analysis, project preparation, and policy dialogue for municipal reform during implementation

\section{0 million \\ $322 \mathrm{MLD}$ \\ - $2,000 \mathrm{~km}$}

\section{- Not targeted}

Not targeted; $86 \%$ achieved

- Not designed, but provided in a

few towns with scope change

- Not designed

- Reform for governance and internal resource mobilization
$\$ 270$ million (4 loans)

- 2006-2016

25 towns

water supply, sewerage systems,

stormwater drainage,

slum improvement, and

infrastructure for tourism and

lake development

$\rightarrow$ Feedback from the KUDCEMP sector analysis, participatory sector analysis, participatory
project planning in the selection project planning in the selection
of towns, and sector reform

\begin{tabular}{|c|c|}
\hline 1.5 million (design) & 1.3 million (design) \\
\hline 180 MLD (design) & 69 MLD (design) \\
\hline 3,600 km (design) & 2,940 km (design) \\
\hline
\end{tabular}

- Targeted for 13 towns

- Targeted for 13 towns

- Designed in 13 towns

- Designed in 13 towns

- Efficiency improvement for water operation

- \$150 million (2 loans)

- 2014-ongoing

7 towns

water supply and sewerage system; Output-Based Assistance Tollet Program (grant [\$1.8 million])

$\rightarrow$ Feedback from the NKUSIP, sector analysis and project preparation through water resource management approach, and sector reform

Illkal Model $\quad$ KIUWMIP Model




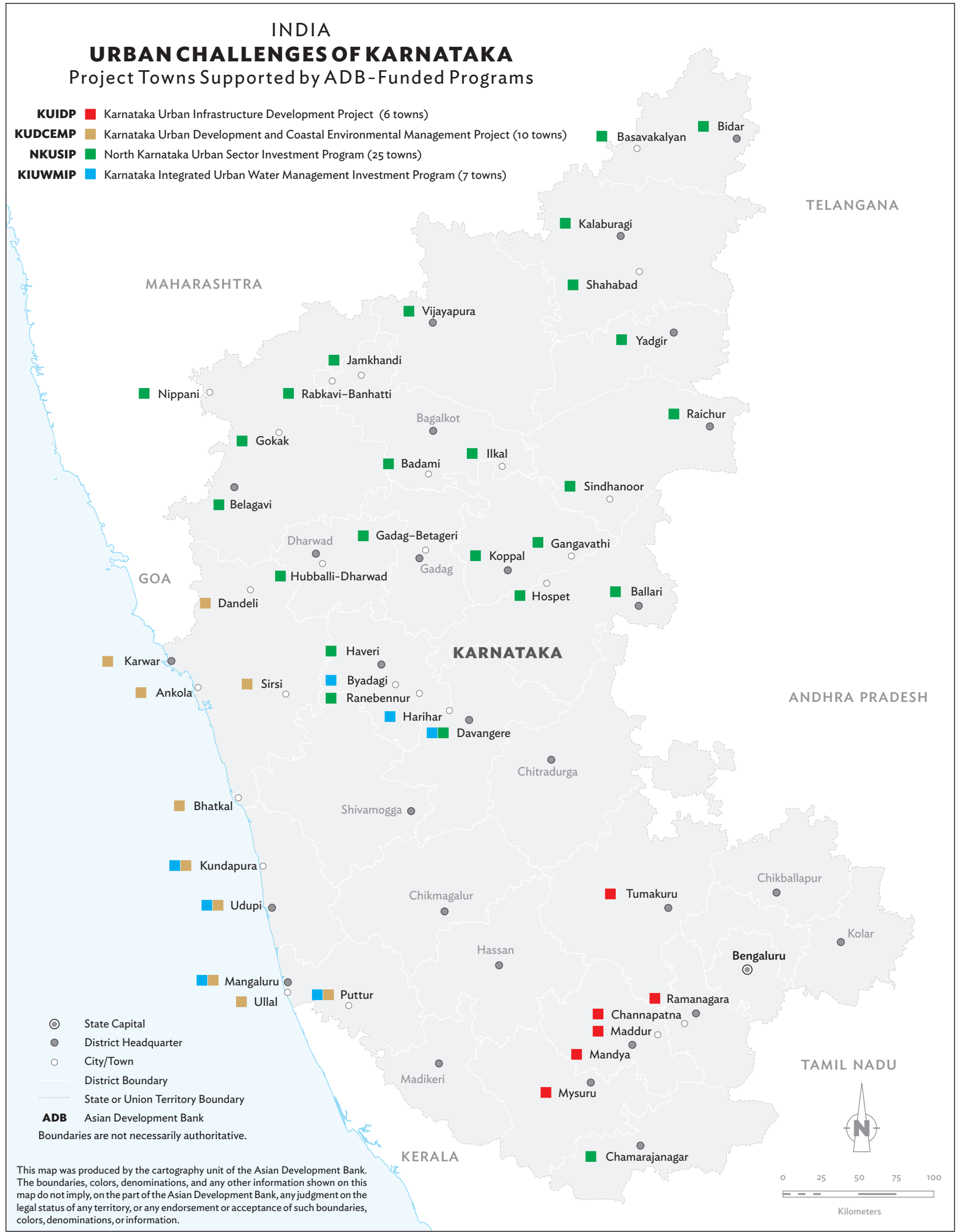

\section{KARNATAKA AT A GLANCE}

- Population: 61 million people accounting for 5\% of India's population (2011 Census); 71 million people (2020 projection)

- Geographical area: India's seventh-largest state (192,000 square kilometers)

- Gross state domestic product: Ranked 4th in Indian states, accounting for $8 \%$ of gross national domestic product (current prices at 2015-2016)

- Per capita net state domestic product: Ranked 7th in Indian states (current prices at 2015-2016)

- Urban population:

- 24 million at 39\% of total population; above national average of 31\% (2011 Census)

- $31 \%$ growth of urban population from 2001 to 2011, compared with 7.6\% growth in the rural population (2011 Census) 

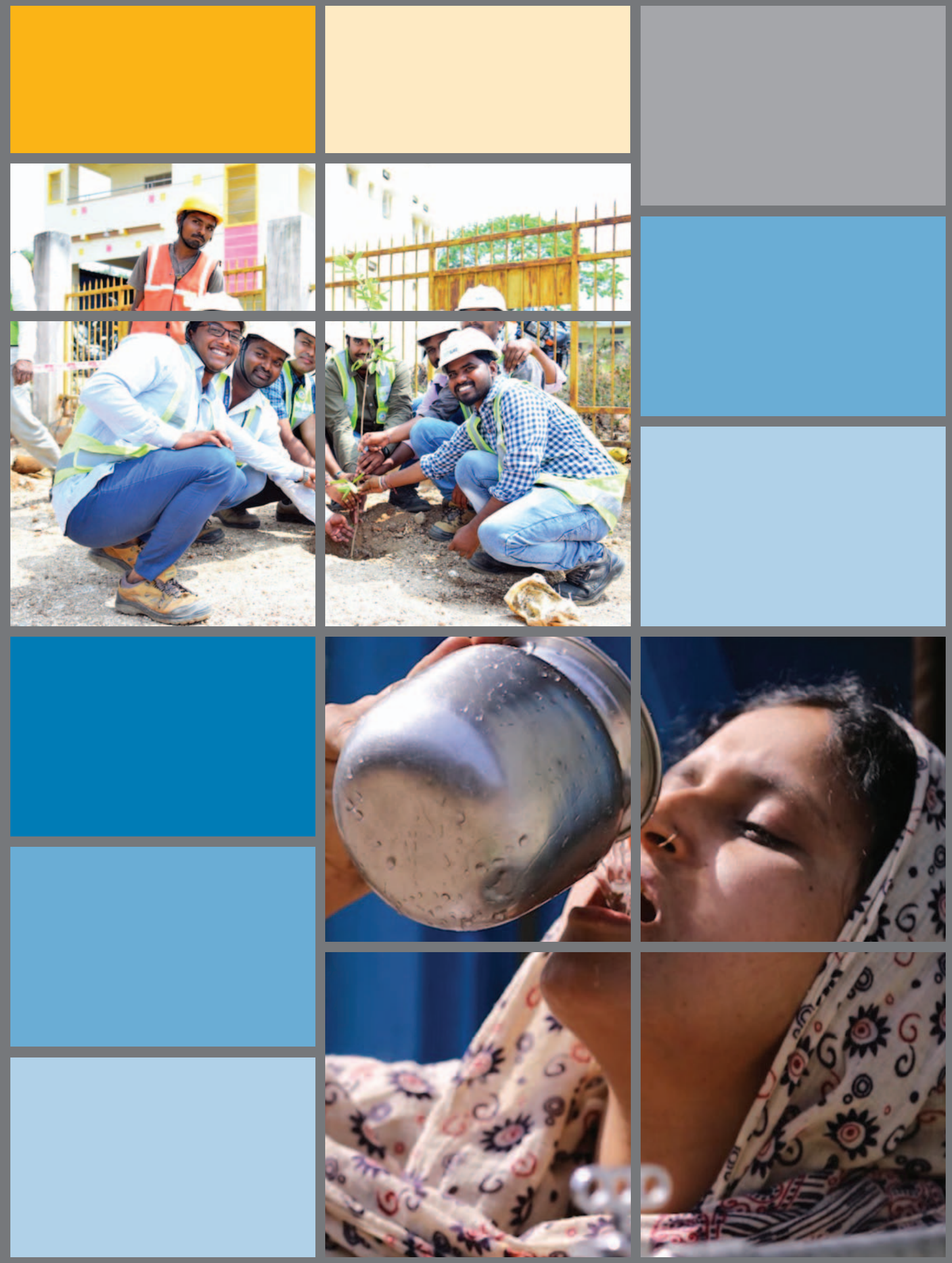


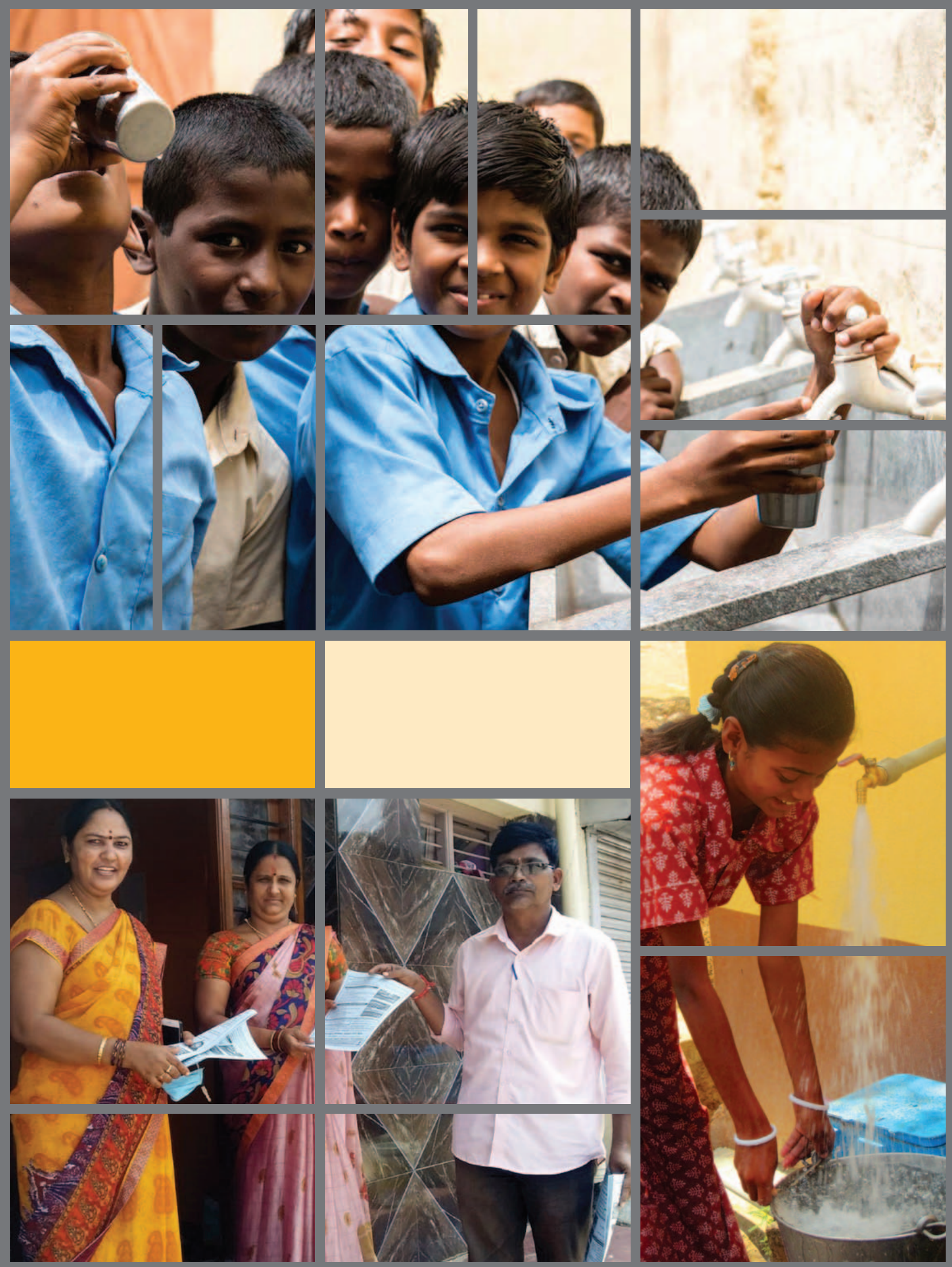




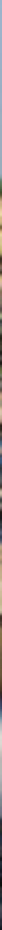

Partnership between the Asian Development Bank (ADB) and the Government of Karnataka began with the Karnataka Urban Infrastructure Development Project (KUIDP), which ran from 1995 to 2002.

\section{A. Overview of the Karnataka Urban Infrastructure Development Project}

In the 1990s, the city of Bengaluru started experiencing disruptive rural-to-urban migration pressure as industrialization and strong growth in its information technology (IT) services spurred urbanization. The state government decided to ease pressure on Bengaluru by developing growth centers nearby as counter magnets. It formulated an integrated urban development project for Bengaluru and its environs, with technical support from ADB. The project was designed to decentralize population and economic growth away from the rapidly expanding urban area by filling infrastructure deficiencies in surrounding areas and reversing environmental deterioration.

On 14 December 1995, the ADB Board of Directors approved a loan for the KUIDP as the first ADB-financed urban sector project in India. The original loan of $\$ 85$ million, later reduced to $\$ 80$ million, was to finance various infrastructure components to augment water supply; rehabilitate and expand sewerage systems; improve solid waste management; construct stormwater drainage; upgrade urban roads; improve traffic management; upgrade slums; and develop industrial sites in six towns: Channapatna, Maddur, Mandya, Mysuru, Ramanagara, and Tumakuru. 
The state government named as the executing agency Karnataka Urban Infrastructure Development and Finance Corporation Limited (KUIDFC), which had been established in 1993 during the processing of the KUIDP as a nodal agency for urban infrastructure development. KUIDFC's major responsibilities were to formulate infrastructure development projects in urban areas; mobilize funds from various financing institutions, including the central government and external development partners; and implement and monitor projects. As this was the first externally aided project assigned to KUIDFC, ADB provided a technical assistance to build KUIDFC's capacity.

\section{B. Lessons from the Karnataka Urban Infrastructure Development Project}

KUIDFC required the capacity necessary to plan, design, and implement new infrastructure and to fill a resource gap in the municipal governments. While the KUIDP achieved its objective of upgrading infrastructure, especially to improve water supply and sanitation in project towns including low-income areas and slums, frequent changes in the leadership of KUIDFC and inadequate consultation with project towns initially undermined the implementation and local government ownership of the project. The 74th constitutional amendment mandated the urban local bodies (ULBs) to plan, implement, and manage basic municipal services including water supply and sanitation. Although the ULBs had capacitybuilding support from ADB, lack of funds and human resources constrained their capacity to fulfill their mandated functions. They, therefore, had to depend on KUIDFC possessing strong executing capacity and effective consultation mechanisms with stakeholders. Recognizing this need, the state government initiated extensive hand-holding support to the ULBs and extensive consultation with stakeholders, thereby successfully putting project implementation back on track.

However, the KUIDP implementation focused on constructing infrastructure assets, without adequate attention to their operation and maintenance (O\&M). Many of the new facilities were reportedly not yet in use 18 months after works were completed, as ULBs had inadequate capacity to take over, operate, and maintain the assets. This experience illustrated that projects should establish handover arrangements to help small towns operate and manage new facilities during the first few years after their commissioning. In the transition period, small towns require supportive institutional arrangements that build their technical and financial capacity. 
greatest potential for economic growth along the coastal region. To address infrastructure deficiencies and tap the economic potential of the region based on the assessment of the project preparatory technical assistance, ADB approved a loan of $\$ 175$ million for the project in October 1999. ${ }^{1}$ The project had five major components: (i) water supply system rehabilitation and expansion; (ii) urban environmental improvement through the construction of sewerage systems; (iii) street and bridge improvements; (iv) coastal environmental management; and ( $v$ ) capacity building, community participation, and poverty reduction (Table 1 ).

Table 1: Outcome of the Karnataka Urban Development and Coastal Environmental Management Project (Water Supply)

Parameter

People benefited with improved potable water supply

House service connection

Average hours of supply

\section{After Project}

1.0 million people (a sample household survey showed that $86 \%$ of households in the project towns have access to piped water).

The project's original scope did not intend to provide household connections and water metering. During implementation, the scope was modified to include household connections in four towns (Kundapura, Puttur, Udupi, and some parts of Ullal).

Ranging from 6 to 16 hours (e.g., 16 hours in Udupi, 8 hours in most areas in Kundapura, and 6-8 hours in Puttur).

Source: Asian Development Bank.

\section{Key Feature: House Service Connections}

While the original scope of the KUDCEMP did not include house service connections or water metering, the project scope was changed to provide household connections up to homeowner property boundaries in the towns of Kundapura, Puttur, Udupi, and some parts of Ullal. The change in project design aimed to encourage more households to shift from the leaky old water supply network to the new one. This was the first attempt in Karnataka to provide end-to-end water supply services.

This change was a departure from earlier practice, which held homeowners responsible for the cost of laying service connection pipes from the water distribution line to their premises. It reflected the growing commitment of the Government of Karnataka and ADB to deliver not only basic public infrastructure but better quality services and easier access to them. ADB-financed urban projects in Karnataka, after the KUDCEMP, stipulated the inclusion of house service connections in their project scope.

\section{Key Feature: Community Awareness and Participation Program}

The KUDCEMP was one of the first ADB-supported projects in India to adopt a participatory approach to implementation through a community awareness and participation program (CAPP). The CAPP targeted

1 The ADB loan was reduced in 2002 to $\$ 145$ million at the borrower's request. 
local communities and the urban poor through community-based organizations, aiming to raise awareness of the benefits of improved water supply and sanitation and the need for tariff reform that would ensure sustainability over the long term. Poverty reduction efforts deployed gender-focused interventions through the creation of women's self-help groups (SHGs) to establish group savings and credit, impart training for skills and entrepreneurial development, and provide livelihoods for underprivileged youths.

The CAPP was implemented in all 10 coastal towns, with assistance from two local nongovernment organizations (NGOs). Nearly 2,500 SHGs were formed to engage some 30,000 low-income families, with $90 \%$ of members being women. Over the project period, SHGs mobilized more than ₹50 million ( $\$ 0.59$ million) through their own savings and disbursed internal loans worth ₹120 million ( $\$ 1.41$ million), directly benefiting over 150,000 people. The project also supported underprivileged youths to improve their livelihoods. About 1,800 students from low-income families, most of them girls, received training in in-demand skills in the IT and hospitality industries, enabling them to explore suitable job opportunities in the private sector.

\section{Key Feature: Public-Private Partnership for the Mangalore Sewage Treatment Plant}

This KUDCEMP subproject demonstrated that partnership between stakeholders can work for their mutual benefit, and that wastewater can be transformed from an environmental liability into a valuable resource. The KUDCEMP supported the construction of the Mangalore Sewage Treatment Plant for the collection, transmission, and primary and secondary treatment of municipal wastewater in the city. The Mangalore City Corporation reached a public-private partnership agreement with the Mangalore Special Economic Zone (SEZ) to enable selected industries to reuse the wastewater treated at the sewage treatment plant set up by the city corporation.

The plant contributed to the efficient use of water and water conservation in Mangaluru, where industrial demand for water is huge. As one of India's most successful SEZs, the Mangalore SEZ was spending a lot of money to buy limited supplies of water. The agreement mandated that, in return for using treated effluent, the SEZ would bear $70 \%$ of O\&M costs for pumping stations and sewage treatment plants managed by the city. Treated water is further processed in a tertiary treatment plant set up by the SEZ to make it fit for industrial use (Box 1). As industrial demand for water continues to grow, the SEZ plans to scale up treatment by constructing two more tertiary plants. This public-private partnership became a model for other urban centers to replicate.

\section{Key Feature: Municipal Reform Program and a Model for India}

During the project implementation, the Government of Karnataka launched the municipal reform program, the Nirmala Nagar Program (translated as Clean Town Program), through policy dialogue with ADB.

The reform program supported computerization of basic municipal functions, modernization of the property tax system, introduction of a fund-based double-entry accrual accounting system, and establishment of participatory planning. These initiatives increased property tax collection in participating towns, improved transparency and accountability in the functioning of the ULBs, helped set up websites, and established public grievance cells operated with the involvement of NGOs (Table 2). 
Box 1: Major Features of the Public-Private Partnership with Mangalore Special Economic Zone

- Incorporation of a special purpose vehicle, Mangalore Sewage Treatment Plant (STP) Limited with 70\% shareholding by Mangalore Special Economic Zone (SEZ) Limited and 30\% by Mangalore City Corporation.

- Operation and maintenance of three secondary sewage treatment plants and connected pumping stations constructed by Mangalore City Corporation under the Asian Development Bank (ADB) project, the Karnataka Urban Development and Coastal Environmental Management Project, through Mangalore STP Limited.

- Mangalore STP Limited spends about ₹160 million (\$1.88 million) in annual operation and maintenance of the three secondary sewage treatment plants and connected pumping stations, with 70\% of cost shared by Mangalore SEZ Limited and $30 \%$ by Mangalore City Corporation.

- Mangalore SEZ Limited constructed a tertiary sewage treatment plant, with 22.7 million liters per day (MLD) capacity using ultrafiltration membrane technology for treatment of secondary treated sewage water from Kavoor sewage treatment plant.

- Around 22.7 MLD of wastewater is being recycled and reused for industrial purposes, with an additional quantity of 20.8 MLD wastewater planned to be reused in the near future.

- The treated water from the tertiary treatment plant is being used by Mangalore SEZ Limited for its industries, thereby reducing dependency on natural water resources.

- The total capital investment of Mangalore SEZ Limited is ₹1,191.6 million ( $\$ 14.01$ million).
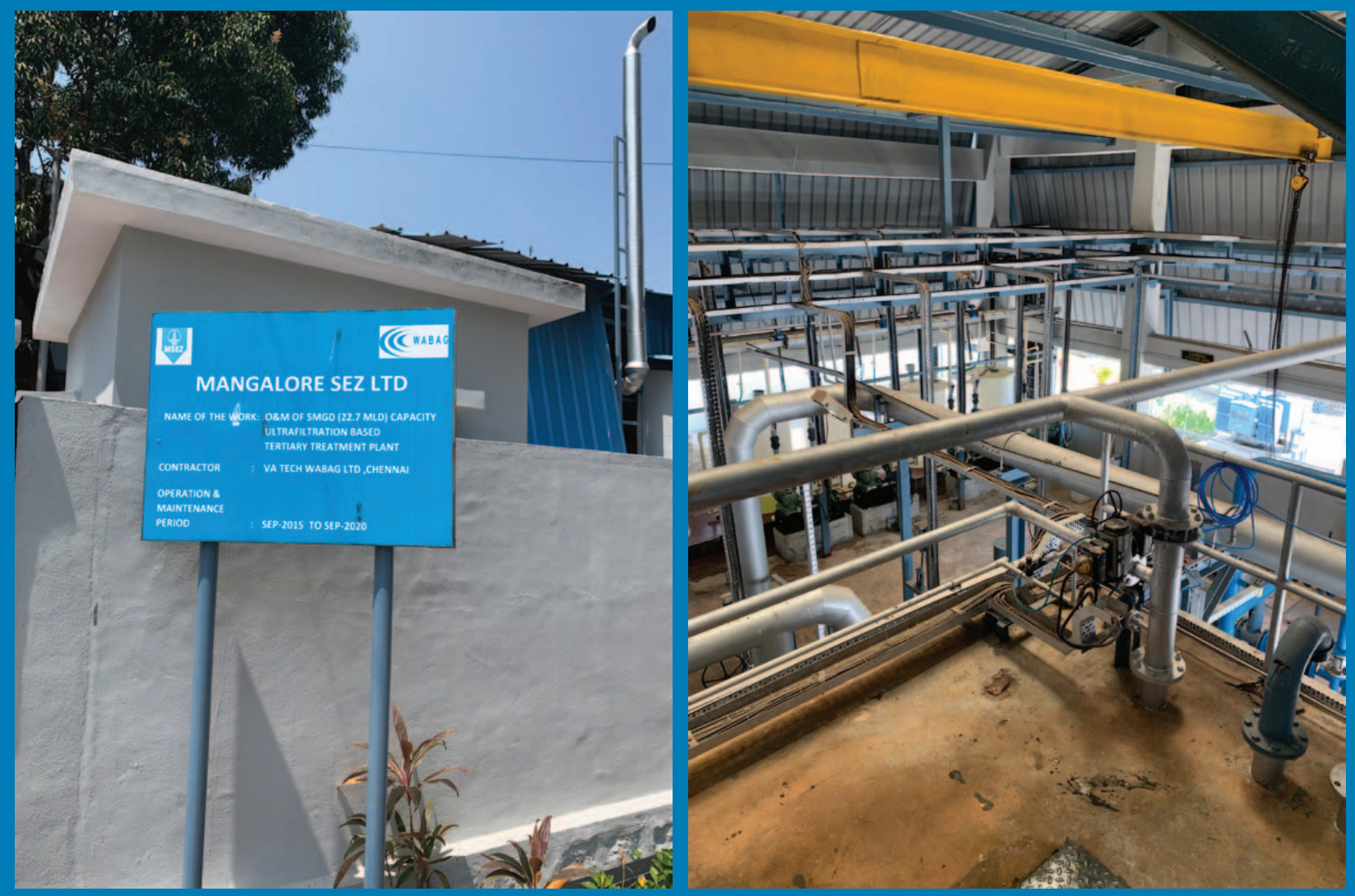

$\triangle$ Tertiary water treatment in the Mangalore Special Economic Zone. It has the capacity of 22.7 MLD to treat secondary treated sewage water (photos by ADB). 
Table 2: Impact of the Municipal Reform Program under the Karnataka Urban Development and Coastal Environmental Management Project

\begin{tabular}{|c|c|c|}
\hline Module & Usage & Impact \\
\hline $\begin{array}{l}\text { Computerization } \\
\text { of basic municipal } \\
\text { functions, including } \\
\text { birth and death } \\
\text { registration }\end{array}$ & $\begin{array}{l}\text { (i) } 8 \text { million births and deaths } \\
\text { registered, and certificates issued } \\
\text { (ii) Websites, with a uniform } \\
\text { design, developed for all urban } \\
\text { local bodies (ULBs), with key } \\
\text { information }\end{array}$ & $\begin{array}{l}\text { (i) Processing time to get certificate reduced from } \\
3 \text { months to less than } 2-3 \text { days } \\
\text { (ii) More than } 600 \text { person-years saved for citizens } \\
\text { (iii) } 200 \text { person-years saved for government officials }\end{array}$ \\
\hline $\begin{array}{l}24 / 7 \text { grievance redressal } \\
\text { with nongovernment } \\
\text { organization involvement }\end{array}$ & $\begin{array}{l}\text { (i) Over } 1 \text { million complaints } \\
\text { redressed }\end{array}$ & $\begin{array}{l}\text { (i) Average complaint redressal time has been } \\
\text { reduced from } 30 \text { days to } 3 \text { days } \\
\text { (ii) Citizen's convenience }\end{array}$ \\
\hline Property tax & $\begin{array}{l}\text { (i) Tracking over } 1.4 \text { million } \\
\text { properties } \\
\text { (ii) } 800,000 \text { unassessed properties } \\
\text { brought under tax-net }\end{array}$ & $\begin{array}{l}\text { (i) ULBs' revenue increased by about } 100 \% \\
\text { (ii) Over } 54 \% \text { unassessed properties in } 49 \text { ULBs } \\
\text { brought under tax-net } \\
\text { (iii) Transparency }\end{array}$ \\
\hline Financial accounting & $\begin{array}{l}\text { (i) Migrated from a cash-based } \\
\text { system to a double-entry } \\
\text { accrual-based system } \\
\text { (ii) Computerization of accounts } \\
\text { with a unified codification }\end{array}$ & $\begin{array}{l}\text { (i) All } 49 \text { ULBs have published their balance sheets } \\
\text { from the system } \\
\text { (ii) Disclosure of the audit report within } 6 \text { months } \\
\text { of the closure of the year } \\
\text { (iii) Planning process of ULBs has become } \\
\text { more participatory, with introduction of public } \\
\text { consultations during budget preparation }\end{array}$ \\
\hline
\end{tabular}

Note: Calculations based on preliminary analysis. Total number of beneficiaries is around 10 million.

Sources: Asian Development Bank and eGovernments Foundation.

\section{B. Lessons from the Karnataka Urban Development and Coastal Environmental Management Project}

Providing high-quality services should be an explicit target in water supply projects. While the KUDCEMP included water service connection to houses to secure benefits to end users, provision of 24/7 water supply was not initially an intended project outcome. However, intermittent water supply is more costly because it renders pipes less durable and poses a risk of system contamination. With this lesson learned, subsequent projects have explicitly targeted the provision of $24 / 7$ water supply in project designs.

Simple project scope can mitigate coordination problems in implementation, and the project schedule should reflect the complexity of project design. The KUDCEMP had 14 major outputs from 6 components in 10 cities across a wide range of geographic areas. This challenged KUIDFC's ability to coordinate, implement, supervise, and monitor all subprojects. Such complex project implementation arrangements with various stakeholders stretched the ability of KUIDFC to address numerous issues. Moreover, the original project implementation period of 5 years suffered a 4-year delay. The project schedule should, 
therefore, be realistic, taking into account (i) technical complexities, as sewerage system improvement encounters unforeseen underground hindrances; (ii) limitations affecting the capacity of executing and implementing agencies, consultants, and contractors; and (iii) seasonal work constraints at project sites.

After project completion, the new infrastructure was handed over to the municipal governments for O\&M. However, low technical capacity and insufficient cost recovery for O\&M were observed in the KUDCEMP. Considering that consumers are unwilling to pay user charges unless services are adequate, the project should ensure continuous water supply to households while conducting extensive public awareness campaigns to garner public support. As will be discussed in the subsequent paras, innovative project designs with a new contract modality and extensive CAPP have been adopted in subsequent projects in North Karnataka. Further, municipalities should have incentives to enforce appropriate water tariffs and improve tariff collection efficiency on a clear timeline, as was done in the Karnataka Integrated Urban Water Management Investment Program through its ULB incentive funds. 
The NKUSIP invested in basic urban infrastructure in 25 towns, providing water supply systems, sewerage and drainage systems, slum improvements, as well as other infrastructure for tourism and lake development. Rather than adopt a conventional approach focused on capital investments, the program emphasized suitable service delivery and enlistment of the private sector for more efficient O\&M of water supply schemes. Further, it promoted institutional development such as through the preparation of a property database with the aim of increasing property tax revenue, the introduction of volumetric water supply tariffs, more efficient water bill collection, and the introduction of sewerage tariffs.

The NKUSIP was a pioneer in establishing the current standard for service requirements for ADB-supported water supply projects in South Asia: 24/7 well-pressurized water supply, 100\% coverage, house service connections, nonrevenue water (NRW) reduction through district-metered area (DMA), and a contract modality that features a longer period of O\&M. This standard was piloted in Ilkal town and scaled up in 12 more towns in North Karnataka. Rigorous community development was also a key feature of the NKUSIP, and it became evident that sensitization campaigns were essential program componentsthey were necessary to raise awareness of the importance of water supply, sanitation, and hygiene, and to garner support from local people for water supply projects.

\section{Key Feature: Ilkal, the First Indian City to Achieve 24/7 Water Supply}

Ilkal, a small town in North Karnataka known for its Ilkal sarees and red granite, suffered from intermittent water supply services; the system reached only $57 \%$ of residences with only intermittent water supply. Poor water supply services perpetuated a downward spiral, leaving customers unwilling to pay water tariffs, revenue insufficient for system maintenance (let alone improvement), and further service deterioration.

In Ilkal, an innovative modality was designed to facilitate improved and sustainable water service delivery through (i) optimal risk allocation between the public sector for project design and a private operator for project construction and operation, and (ii) performance-based payment to encourage the private operator to complete construction in a timely manner and with better quality of service. Under a performance-based construct and operate contract (PBCOC), the private operator carries out construction according to detailed designs provided by the public sector and operates the system for 4 years before transferring O\&M back to the public authority (Table 3).

The PBCOC model works well for water supply improvement because it holds a single contractor responsible for both construction and O\&M. The arrangement ensures that contractors deliver high-quality infrastructure, as their future remuneration depends on their performance during the O\&M phase. Remuneration based on bills of quantities during construction reduced risks to the contractor in brownfield projects, particularly from uncertainty about underground physical assets. Moreover, the incentive mechanism encourages timely commissioning and sustainable operation. During construction, operator remuneration is fixed but with potential for a bonus to reward early completion. During operation, in addition to the fixed payments, remuneration includes performancebased bonuses for meeting established indicators of continuous supply, NRW reduction, a minimum pressure standard, and customer service targets. 
Table 3: Modality of a Performance-Based Construct and Operate Contract

\begin{tabular}{|c|c|c|c|c|c|}
\hline \multirow[b]{2}{*}{ Contract Model } & \multicolumn{3}{|c|}{ Responsibilities } & \multirow[b]{2}{*}{ Financing } & \multirow[b]{2}{*}{ Remuneration } \\
\hline & Design & Build & Operate & & \\
\hline $\mathrm{PBCOC}$ & & & & & $\begin{array}{l}\text { Fixed during construction, with } \\
\text { potential early completion bonus } \\
\text { Fixed and performance-based } \\
\text { during operations }\end{array}$ \\
\hline
\end{tabular}

Public responsibilities

Private operator's responsibilities

$\triangle$ Other contractors recruited by the private sector

$\mathrm{PBCOC}=$ performance-based construct and operate contract.

Source: Adapted from Asian Development Bank. 2017b. 24/7 Normalized Water Supply Through Innovative Public-Private Partnership: Case Study from Ilkal Town, Karnataka, India. Manila. Table 1. p. 4.

The PBCOC arrangements succeeded in providing normalized water supply, reducing NRW, encouraging water conservation, and recovering costs for O\&M. As in the case of Ilkal, the PBCOC was particularly effective when used through DMAs, which are hydraulically isolated from bulk water transmission mains and neighboring areas to facilitate the effective management of water pressure, balance, and leakage. Physical losses fell from 50\%, before the NKUSIP, to less than $8 \%$. Further, water consumption was significantly reduced to below 100 liters per capita per day, against an Indian standard of 135 liters. These water savings were apparently made possible by consumers abandoning an old habit under intermittent supply of storing excessive amount of water and later discharging what turned out to be surplus. After system commissioning, ADB initially provided O\&M cost support, which tapered gradually over a few years. By the end of 2019, O\&M expenditure was fully covered by user charges, and the O\&M contract has been extended between the municipality and the contractor. High tariff collection efficiency means the municipal government does not need to subsidize O\&M (Table 4).

Table 4: Impact of 24/7 Water Supply Project in Ilkal Town under the North Karnataka Urban Sector Investment Program

\begin{tabular}{lll} 
Parameter & \multicolumn{1}{c}{ Before Project } & \multicolumn{1}{c}{ After Project } \\
Hours of supply & $2-4$ hours in alternate days & $24 / 7$ supply \\
Average pressure in distribution system & $0-1.5$ meters & 14.0 meters average pressure \\
Population served & $\begin{array}{l}\text { No household connections; only } \\
\text { through } 230 \text { public stand posts }\end{array}$ & $\begin{array}{l}100 \% \text { population with individual house } \\
\text { service connections }\end{array}$ \\
Physical losses & $50 \%$ & $8 \%$ \\
Metering & No individual connections & $100 \%$ metered connections \\
Customer complaints response time & Not applicable & Complaints addressed within 24 hours \\
Collection efficiency & Not available & More than $90 \%$ \\
\hline
\end{tabular}

Note: Total number of beneficiaries is about 90,000 people.

Source: Asian Development Bank. 


\section{Key Feature: Community Development}

Building on the lessons of the KUDCEMP, the NKUSIP included enhanced community awareness programs to highlight hygiene, water supply, and waste management, and to encourage willingness to pay for house connections and volumetric tariffs. These activities were conducted with support from NGOsan apex NGO at the center supervised NGOs implementing in each town gender action and community development plans.

Continuous engagement with water users since the inception of the NKUSIP planning helped ensure the sustainability of infrastructure provided by the program. Awareness campaigns motivated 2,305 families to invest in better household hygiene by way of household taps, underground drainage, sewerage, and household latrines. The project achieved high ownership in the community by facilitating, from project inception, an enabling environment to address stakeholders' concerns about metering and volumetric tariffs, and by clarifying the role of the private operator. Women gained access to economic opportunities through the training of 6,606 self-help group (SHG) members in 575 SHGs to improve their skills and credit worthiness. Training and capacity building enabled 2,292 women in 215 SHGs to access ₹13 million ( $\$ 0.15$ million) in loans from commercial banks to invest in their homes and income-generating activities and earn $₹ 160,000(\$ 1,800)$ in profits.

Gender-focused community development was similarly successful under projects $2-4$ of NKUSIP, which encouraged female-elected representatives to participate in training and exposure visits to enhance their capacity to monitor project interventions, mitigate any shortcomings, and motivate their communities. SHG strengthening was a critical strategy to promote economic empowerment. Project 4 of NKUSIP, in particular, trained community women in unconventional skills, such as plumbing, toward challenging gender-based vocational stereotypes and encouraging female participation in skilled employment.

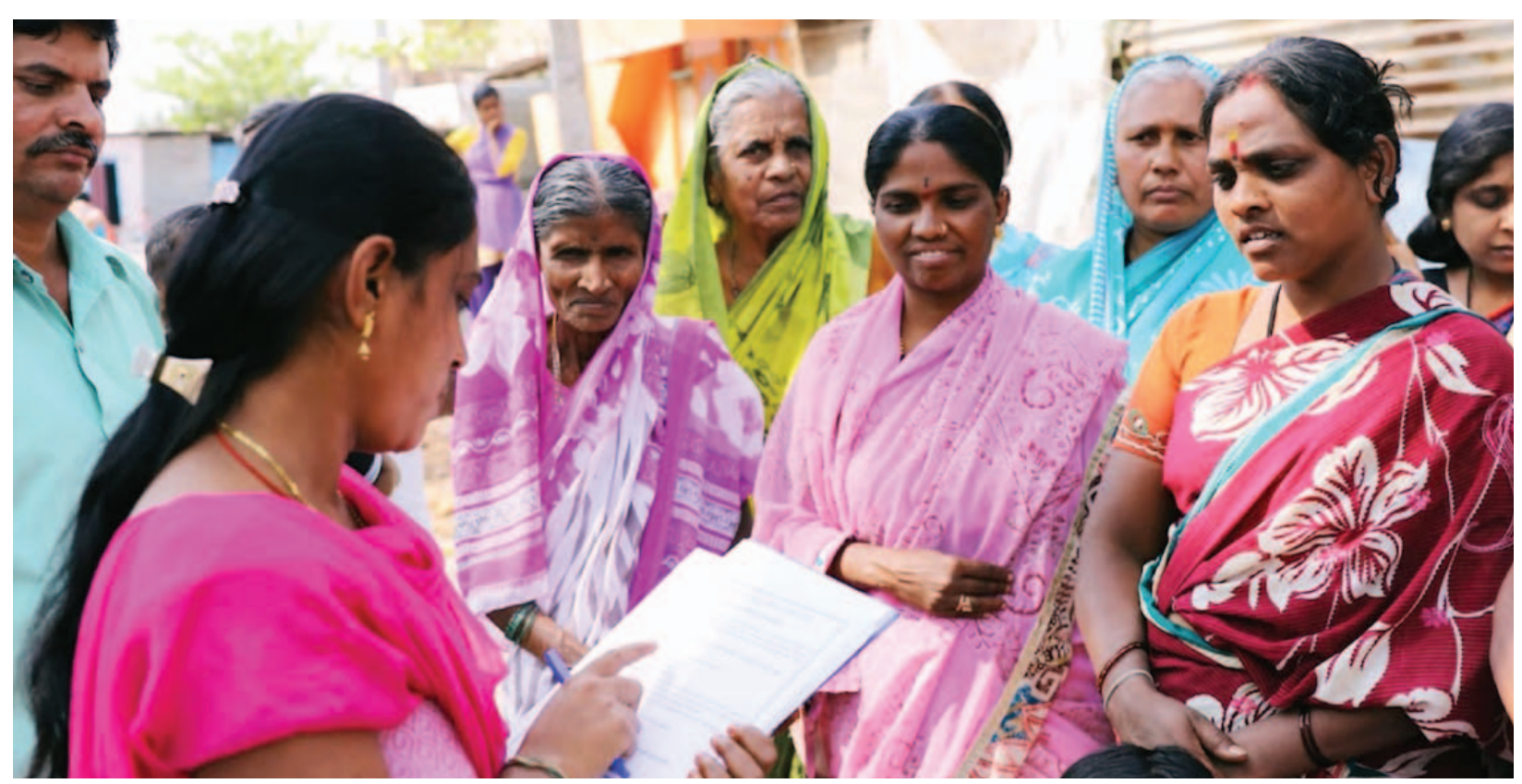

$\Delta$ Continuous engagement with beneficiaries and awareness campaigns in communities. It helped ensure the sustainability of infrastructure provided by the program and promote economic empowerment of community women (photo by Karnataka Urban Infrastructure Development and Finance Corporation Limited). 


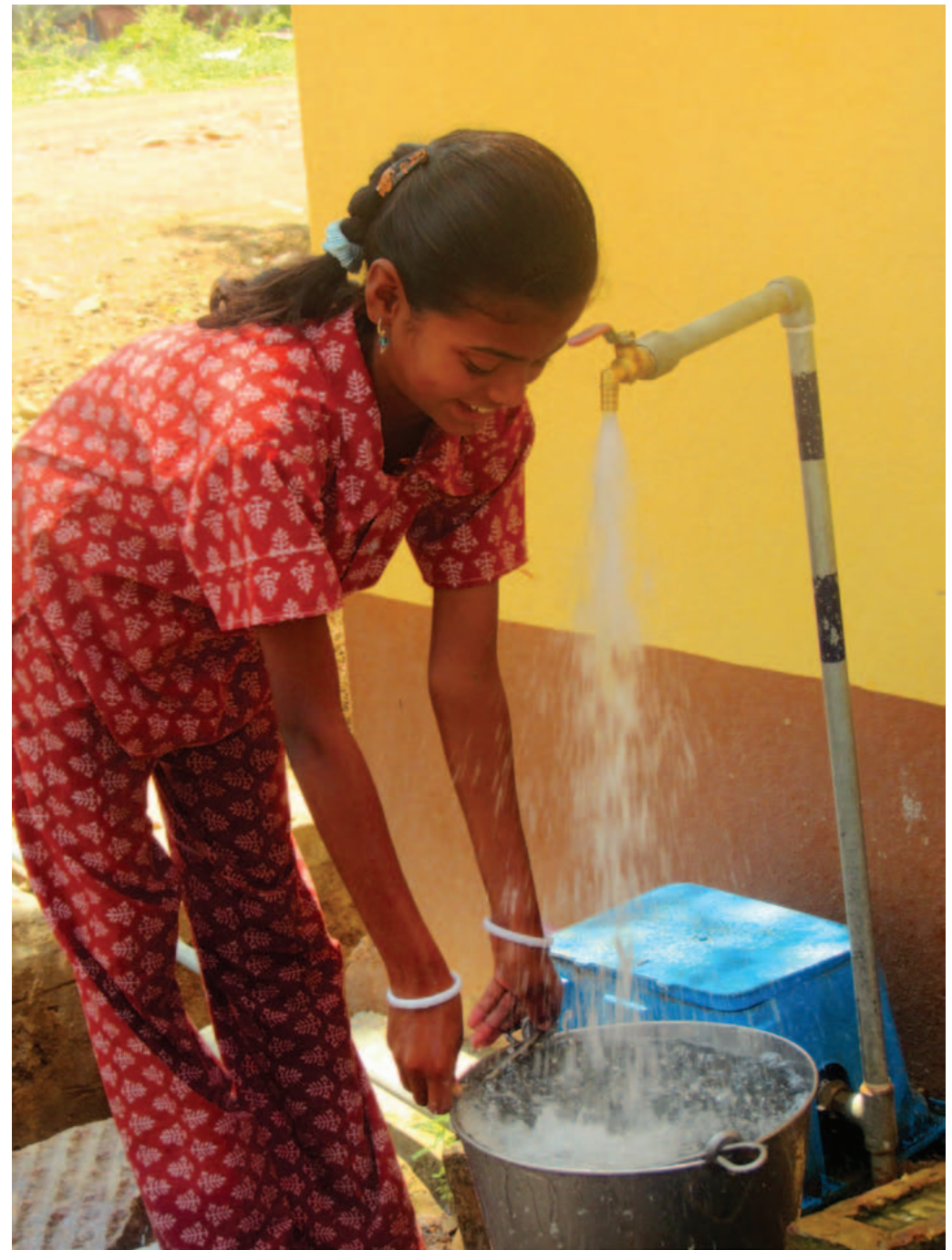

$\varangle$ Water for future. Better access to continuous water services helps women and girls invest more of their time for the future (photo by Karnataka Urban Infrastructure Development and Finance Corporation).

\section{B. Lessons from the North Karnataka Urban Sector Investment Program}

The Ilkal water supply scheme demonstrated that the vision of having a 24/7 water supply can be realized in emerging countries through (i) dedicated team effort, (ii) sound strategies to leverage opportunities and mitigate issues, (iii) participatory planning, (iv) innovative public-private partnership and a PBCOC modality that takes into account the contract-administering capacity of small ULBs, ( $v$ ) balanced risks and rewards, and (vi) good technical planning coupled with a community participation strategy to improve public awareness of the project and build consensus on metered volumetric tariffs. Community involvement in the program from its inception established local ownership, generated an enabling environment that addressed stakeholder concerns about metering and volumetric tariffs, and clarified the role of the private operator. The Ilkal success story proves that social components are as important as technical components for a program's success. 
Ilkal further demonstrated that high-quality service provision can start an upward spiral or virtuous cycle, wherein customers willingly pay user charges, thereby providing sufficient revenue for system maintenance and cost recovery in O\&M as a whole. The model is now being initiated in 12 additional cities under the NKUSIP and was adopted in 7 cities under a subsequent ADB investment program, the Karnataka Integrated Urban Water Management Investment Program (KIUWMIP), as will be discussed in section IV. The PBCOC has proven to be a replicable model in other states such as Rajasthan and Andhra Pradesh. The recent expansion of ADB's water supply interventions in India is facilitating the creation of the PBCOC market, where private sector service providers are participating proactively.

The llkal model showed that impact can be maximized only when certain arrangements are established. The project needs to (i) provide bulk water from reliable and sustainable raw water sources (for Ilkal, from Almatti Dam); (ii) have an executing agency with reasonable technical capacity to prepare detailed engineering designs; (iii) have contractors with the capacity to properly undertake design validations and conduct appropriate O\&M; (iv) implement effective community awareness campaigns to maximize project impact; and ( $v$ ) secure strong commitment to reform from the municipal governments to improve water supply and achieve O\&M cost recovery.

Compared with water supply projects, sewerage projects tend to take longer to reach full utilization. Despite extensive awareness campaigns, several centralized NKUSIP sewerage schemes were underutilized for lack of house service connections. To deliver project benefits within the designed implementation period, (i) project preparation should be rigorously undertaken through advance contracting; (ii) project implementation should be scheduled for 6-7 years, assuming adequate project readiness; and (iii) contingent arrangements after loan closing should be established to complete any remaining works under district leadership. 


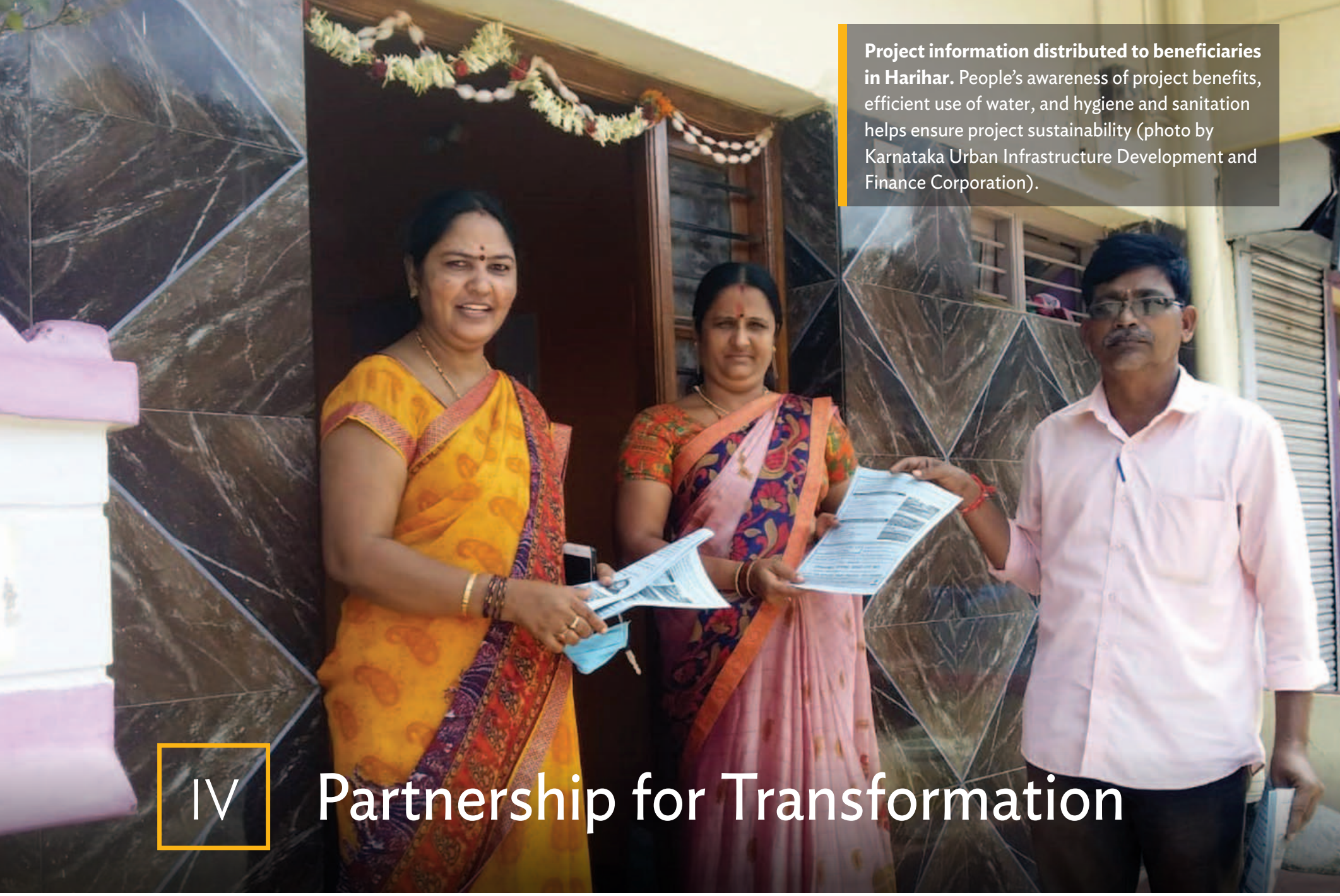

The ongoing KIUWMIP, which began in 2014 and is the fourth ADB engagement in Karnataka, has implemented transformative institutional reform to ensure the sustainability of high-quality water supply and sanitation services.

\section{A. Overview of the Karnataka Integrated Urban Water Management Investment Program}

Rapid urbanization and industrialization in a drought-prone state requires that available water resources be effectively managed. Karnataka has become one of India's most economically progressive states.

The state economy has grown quickly, with annual growth in gross domestic product averaging $7.2 \%$ from fiscal year 2009 to 2012. Accordingly, Karnataka's seven major river basins suffered from over-abstraction of water and deteriorating water quality. Despite steady improvement under KUDCEMP, water supply coverage remained insufficient and service standards inadequate. Only $38 \%$ of ULBs provided enough water to cover basic domestic needs, estimated at 70-135 liters per capita per day, and most towns operated water supply services for only 2-3 hours per day. Sanitation services lagged far behind water supply services across the state, with only $15 \%$ of the urban population using sewage treatment systems. The absence of adequate sewerage networks allowed black and gray wastewater discharges to pollute water bodies. 
The KIUWMIP was designed to enhance sustainable water security, coordinating the planning, development, and management of urban water resources in line with the principles of integrated water resources management (IWRM). The policy dialogue on IWRM framework with the ADB-funded technical support contributed to developing an integrated approach for urban water services such as inclusion of urban water supply and sanitation (UWSS) services infrastructure in river basin planning; development of urban watershed management, water services charter, and water safety plan; and establishment of a water service regulator. The investment program, with ADB contributions of $\$ 150$ million for seven towns, aims to (i) improve and expand UWSS; (ii) enhance institutions to improve water use efficiency, productivity, and sustainability; and (iii) support innovative implementation mechanisms, such as reform-oriented incentive funds.

The program incorporates several key designs that draw on lessons learned from prior projects. It applies 24/7 water supply, 100\% coverage, house service connections, and NRW reduction through DMAs in all project towns. The PBCOC modality piloted in the NKUSIP is applied to all water supply contracts under the KIUWMIP. The program avoids overly complex project scope, limiting interventions to only seven towns in two tranches. Further, transformative institutional reform has been pursued to generate an enabling state policy environment for improved water supply and sewerage, and to establish a mechanism to support reform implementation in ULBs. Through active and committed collaboration, the Government of Karnataka, KUIDFC, and ADB have established the need to scale up good practices and broader institutional changes to ensure the sustainability of O\&M. In other cases, the achievements of project-specific interventions were observed to have remained as success stories at project level and were confined to that geographic location. Many of these successful cases disappeared unnoticed at project closure before such good practices were formalized in the government system. This common concern was the driving factor to making the logical transition from the llkal model (pilot-based and localized interventions) to the KIUWMIP model (full-scale and broader target of institutional changes for a sustainable $O \& M$ ). This could be done on the basis of long-term mutual trust and strong partnership between the Government of Karnataka, KUIDFC, and ADB.

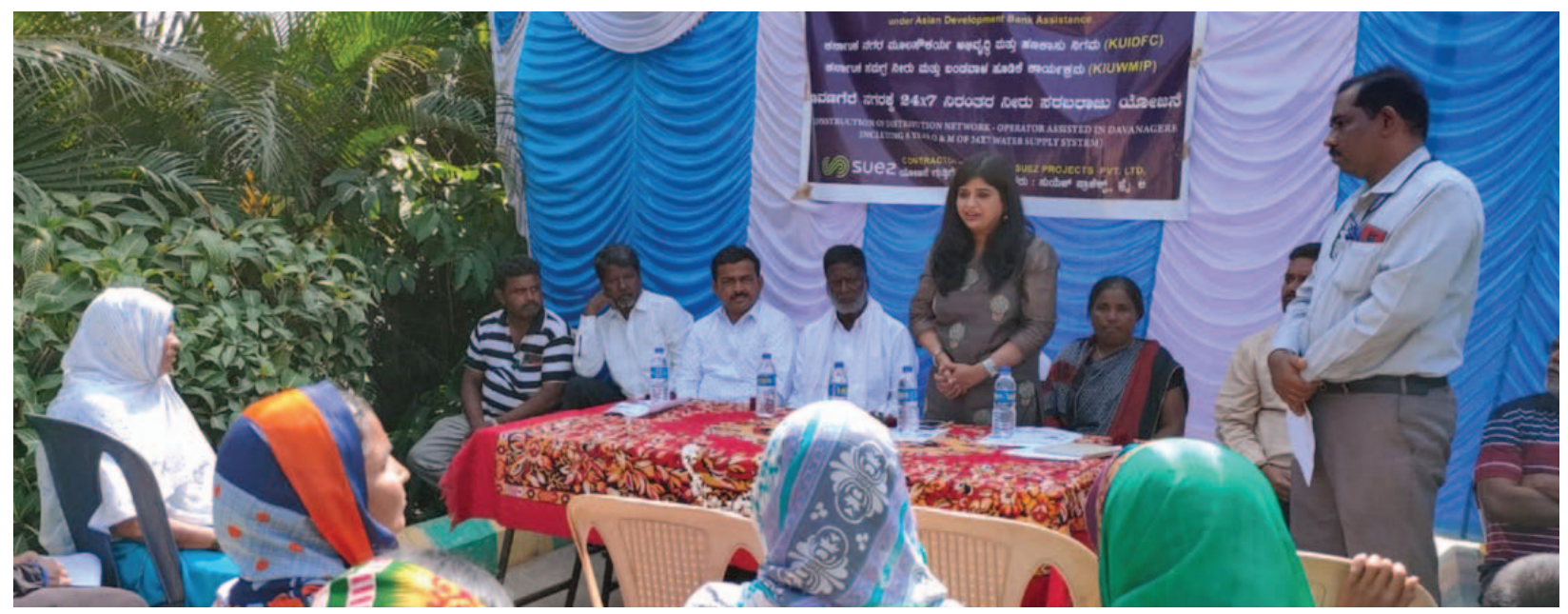

$\Delta$ Building trust with end users. Benefits of uninterrupted high-quality drinking water supply at their doorstep are widely disseminated to improve the living conditions of local people (photo by Karnataka Urban Infrastructure Development and Finance Corporation). 


\section{B. Infrastructure Development}

In project 1 of the KIUWMIP, ADB supports strengthening UWSS infrastructure in three inland towns of the Tungabhadra subbasin. Byadagi, Davangere, and Harihar were selected based on (i) the impact of IWRM improvement on Karnataka's water resources, (ii) the openness of ULBs to reform, and (iii) the towns' infrastructure gaps. The UWSS infrastructure will improve water treatment capacity for water supply and wastewater treatment capacity, as well as improve sewerage networks to strengthen environmental protection. Project 1 , amounting to $\$ 75$ million of ADB's support, targets to provide 550,000 people with $24 / 7$ drinking water in the project towns through piped supply network and metered water connections. The project would benefit about 280,000 people with the construction of sewerage networks, providing the project towns with environment-friendly disposal and treatment options (Table 5). As of April 2020, of the 10 subprojects, 2 subprojects are fully completed, 7 subprojects will be completed by the third quarter of 2020, and 1 in the first quarter of 2022. KUIDFC is installing solar panels at some of the water and sewage treatment plants to meet the captive power requirements.

Building upon the achievements of earlier programs, KUIDFC continues to adopt the PBCOC modality for water supply improvement contracts, wherein the private operator carries out construction according to detailed designs provided by the project authority and operates the system for $6-8$ years.

Table 5: ADB Support to Infrastructure Development under Project 1 (Ongoing), Karnataka Integrated Urban Water Management Investment Program

\begin{tabular}{ll} 
Item & \multicolumn{1}{c}{ Description } \\
Key input & ADB's financial support of $\$ 75$ million in three ULBs in Karnataka: Byadagi, Davangere, and Harihar \\
Impact & Improved sustainable water security in the upper Tungabhadra sub-basin, with improvements in surface \\
water quality (compliant with national standards) and reduction in incidences of waterborne diseases \\
Target \\
(i) Improved water use efficiency through NRW reduction from 40\% to less than 25\% \\
(ii) 550,000 people served with improved piped, metered water connections to guarantee 24 hours of \\
(iii) 280,000 people served with sewers in the three ULBs \\
(iv) National wastewater effluent quality discharge and/or reuse standards met in the three ULBs \\
infrastructure \\
Water supply \\
(i) Water production and water treatment capacity increased by 60 MLD \\
(ii) 1,536 km of pipe network constructed \\
(iii) 118,000 metered house connections (new and replacement of old connections) \\
Sewerage \\
(i) $315 \mathrm{~km}$ of sewage collection pipe network constructed \\
(ii) Sewage treatment capacity increased by 48 MLD \\
(iii) 15,000 new house connections
\end{tabular}

$\mathrm{ADB}=$ Asian Development Bank, $\mathrm{km}$ = kilometer, $\mathrm{MLD}=$ million liters per day, NRW = nonrevenue water, ULB = urban local body. Source: ADB. 


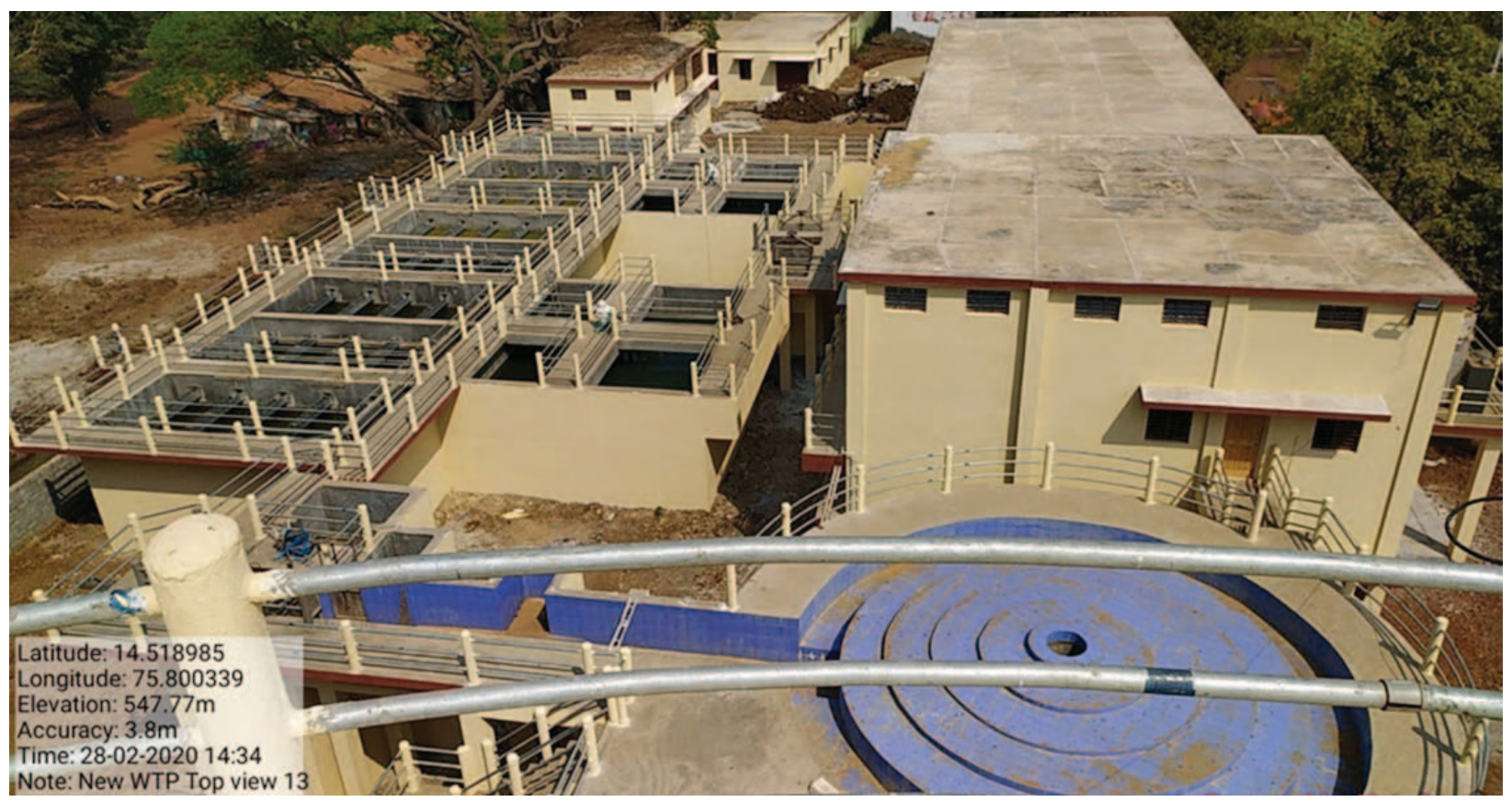

$\Delta$ Water treatment plant in Harihar constructed under project 1. The new plant has the water treatment capacity of 20 million liters per day (photo by Karnataka Urban Infrastructure Development and Finance Corporation).

The contractual arrangements as well as deliverable assets quality were further strengthened by incorporation of geographic information system (GIS)-enabled water asset mapping provided by the contractors at the project ULBs. All the elements envisaged under the ULB reform program are directly interlinked with the deliverables of the PBCOC contracts including updating consumer database, extending service coverage, installing metered connections, developing asset mapping, and building dynamic asset management.

Another notable feature of the KIUWMIP's project 1 is the $\$ 1.8$ million in grant cofinancing for the improvement of sanitation facilities of low-income households, particularly those without access to sanitation facilities, through the Output-Based Assistance (OBA) Toilet Program. Under the program, which is supported by the Urban Environmental Infrastructure Fund under the Urban Financing Partnership Facility, fund payments or subsidies are innovatively linked to the achievement of specified outputs as opposed to the traditional input-based methodology. A major hurdle for the urban poor to obtaining access to sanitation and other basic services is the high initial cost. OBA can reduce this barrier by paying a subsidy to bridge the gap between actual cost and what beneficiary can contribute. In the construction of individual household toilet and its connection to the sewerage network, 10\% of the costs are covered by the beneficiaries, $20 \%$ by the ULB, and $70 \%$ by the grant through KUIDFC. The program is supported by sanitation marketing to promote open defecation-free communities. Local NGOs recruited by KUIDFC and community-based groups are entrusted to oversee the construction progress of the toilets, which is supported by a robust monitoring mechanism structured for the implementation of the grant. The subsidy is provided to the beneficiaries following verification of satisfactory substructure construction, superstructure completion, and operation through these NGOs. Around 5,800 individual toilets are envisaged to be constructed; as of April 2020, 4,400 toilets were completed. 


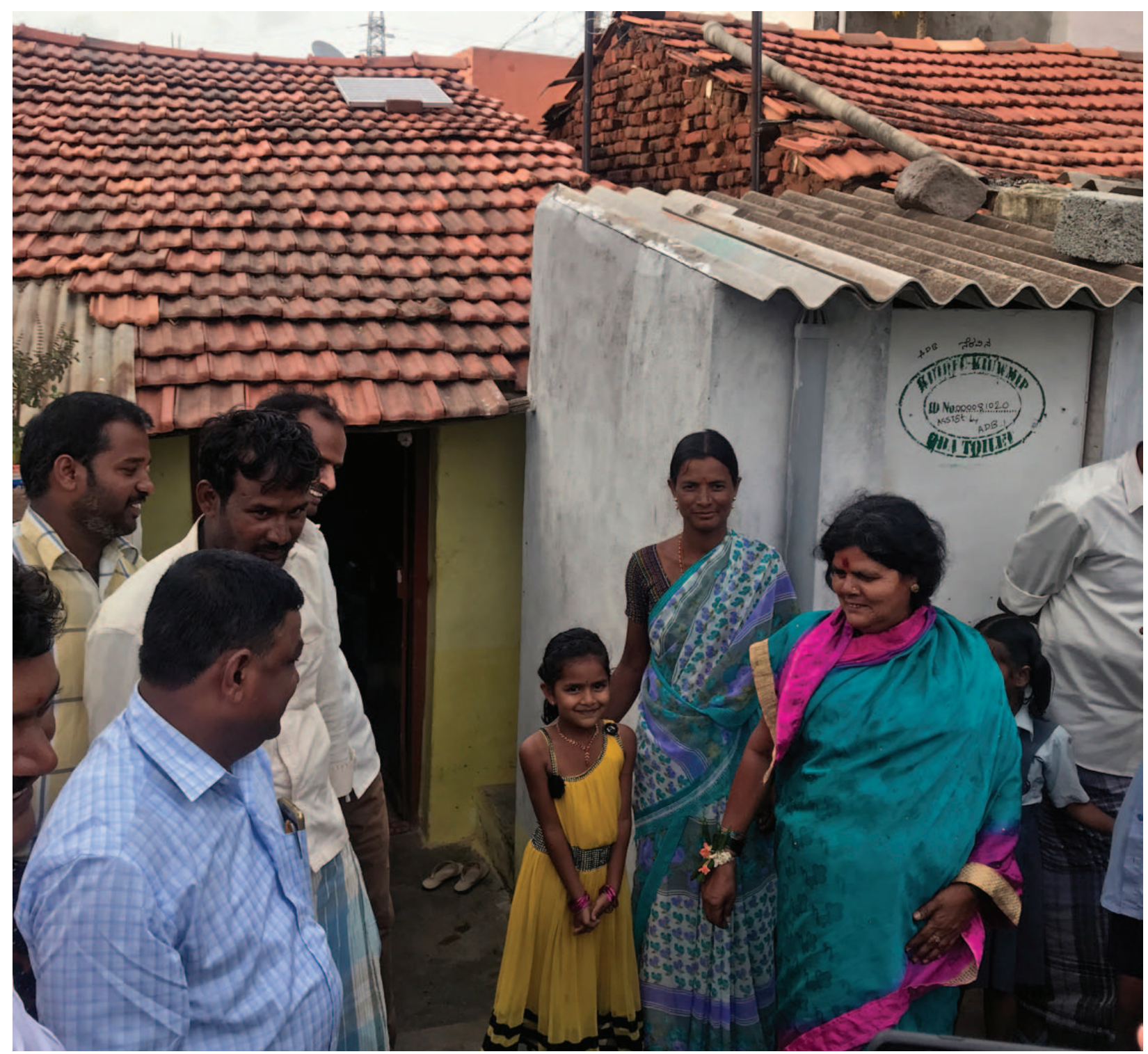

$\Delta$ Individual toilets constructed through the Output-Based Assistance (OBA) Toilet Program. OBA supports the urban poor to obtain access to sanitation by paying a subsidy to bridge the gap between actual cost and what beneficiary can contribute (photo by $A D B$ ).

Project 2 of the KIUWMIP will enhance UWSS services in four coastal towns. Kundapura, Mangaluru, Puttur, and Udupi are in a narrow coastal belt, with the Arabian Sea to the west and the high ridge of the Western Ghats to the east. Despite improvement in the UWSS infrastructure under the KUDCEMP, the rapid pace of economic development and urbanization has put considerable stress on existing UWSS infrastructure. The project, amounting to $\$ 75$ million of ADB's support, is developing water supply systems in three of the towns that promote efficient and sustainable use of water. It includes strengthening the pumping main capacity and expanding coverage in the Mangalore sewerage system (Table 6). Among the four subprojects, the water supply system in Kundapura and the sewerage rehabilitation in Mangaluru will be completed in 2020. 
Table 6: ADB Support to Infrastructure Development under Project 2 (Ongoing), Karnataka Integrated Urban Water Management Investment Program

Item
$\begin{aligned} & \text { Key input } \\ & \text { ADB's financial support of } \$ 75 \text { million in four ULBs in Karnataka: Kundapura, Mangaluru, Puttur, } \\ & \text { and Udupi } \\ & \text { Improved sustainable water security in river basins of coastal Karnataka, with enhanced urban water } \\ & \text { resources management } \\ & \text { Target } \\ & \text { (i) Improved water use efficiency through NRW reduction from } 42 \% \text { to less than 15\% } \\ & \text { (ii) } 765,000 \text { people served with improved piped, metered water connections to guarantee } \\ & \text { (iii) } 193 \text { hours of potable water supply in the four ULBs } \\ & \text { (iv) } 95 \% \text { of potable water samples in four towns complied with the national drinking water quality } \\ & \text { standards } \\ & \text { Water supply } \\ & \text { infrastructure } \\ & \text { (i) Water production and water treatment capacity increased by } 8.7 \text { MLD } \\ & \text { (ii) } 1,410 \text { km of pipe network constructed } \\ & \text { (iii) } 111,600 \text { metered house connections (the replacement of about 78,900 existing house service } \\ & \text { connections with metered connections, and the provision of new metered connections to } \\ & \text { about } 32,700 \text { households) }\end{aligned}$
Sewerage
Rehabilitation of about 11 km of pumping mains

$\mathrm{ADB}=$ Asian Development Bank, $\mathrm{km}$ = kilometer, MLD = million liters per day, NRW = nonrevenue water, ULB = urban local body. Source: ADB.

Projects 1 and 2 follow all good practices established in light of prior projects for promoting sustainable, reliable, and equitable water supply. Project 2 ensured high project readiness through advance contracting. Following lessons from the KUDCEMP and the NKUSIP, project 2 implemented project preparation proactively, with all contracts signed and more than $20 \%$ of disbursement achieved within 1 year after the loan went into effect. The project is conducting extensive community awareness campaigns. More than 200 public consultations are targeted, of which 70 meetings have been completed by April 2020.

In May 2020, KUIDFC was the first agency in ADB's India operations to issue an enhanced health and safety plan aiming to take maximum precautions for worker protection at project construction sites during the coronavirus disease (COVID-19) pandemic. The plan provides standard of procedures for prevention practices in the work sites, including labor camps and washing facility. Any issue of noncompliance shall be a basis for the suspension of work, and the contractors are required to submit to KUIDFC a corrective action plan for their work resumption. This plan became a model guideline for other ADB-funded projects in India. ${ }^{2}$

2 The enhanced health and safety plan is available at KUIDFC's website. KUIDFC. 2020. SOP-Health and Safety Plan: Stop the Spread of COVID-19. May. http://www.kuidfc.com/uploaded_documents/administration/SOP-H\%20and\%20S\%20 Plan\%20Covid\%20approved\%20by\%20MD\%2015.5.2020.pdf. 


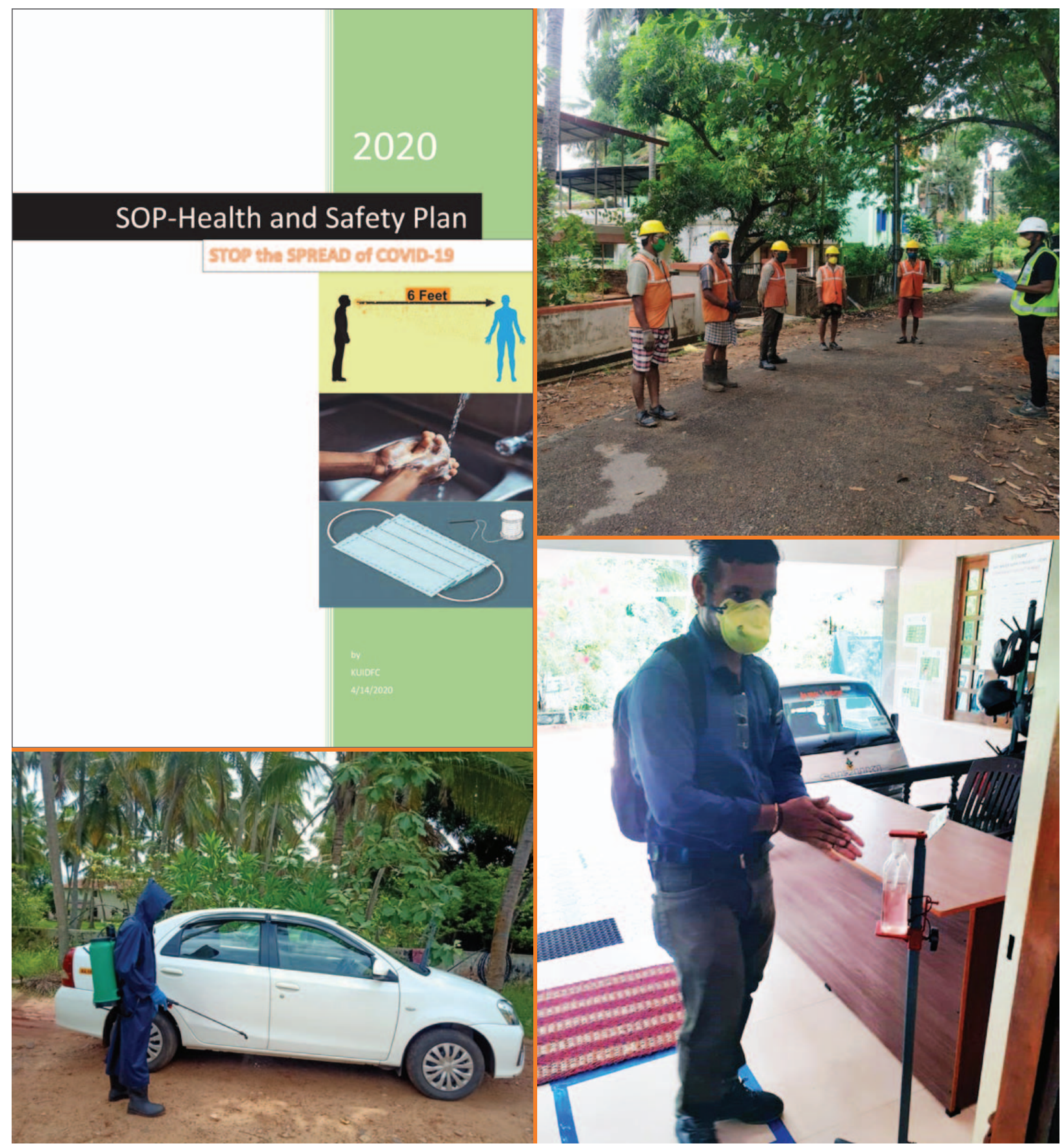

$\triangle$ KUIDFC's enhanced health and safety plan in response to the COVID-19 global pandemic. The plan was prepared to maximize protection and precaution in the work sites under project 2 (photos by Karnataka Urban Infrastructure Development and Finance Corporation). 


\section{Institutional Transformation}

\section{Key Feature: Institutional Transformation with State Policy Reform}

Prior project experience showed that infrastructure development alone cannot deliver sustainable water services. Transformative institutional reform is also required. The KUDCEMP observed insufficient cost recovery for O\&M in the absence of an incentive mechanism for ULBs to institute appropriate tariffs. Ilkal may be a rare case of strong municipality commitment that cannot be assumed in all ULBs. Under a statewide sector framework, an effective mechanism should be established to incentivize and enable municipalities. To sustain the quality of service delivery, ULBs should transform themselves into responsible utility managers by promoting water audits, ring-fenced accounting, volumetric tariffs, and dynamic asset management.

In view of this, the state government has decided to implement sector policy reform to improve urban water management and strengthen technical, environmental, institutional, and financial sustainability in the following areas:

(i) Improved urban water management will be supported through (a) preparation of urban watershed management plans covering water safety and quality and promoting the use of treated wastewater; (b) conduct of urban water management accounting to assess water resources at the ULB level and as a tool to improve efficiency, compliance, and accountability; and (c) establishment of demand management to facilitate the fair and equitable distribution of scarce resources.

(ii) Technical and environmental sustainability will be achieved through (a) asset management to foster better O\&M of UWSS infrastructure and provide more efficient services, and (b) environmental protection to maintain drinking water quality standards and protect water resources from overabstraction and pollution.

(iii) Institutional and financial sustainability will be promoted through (a) effective utility management implementing an enterprise resource management plan and a customer outreach program to improve institutional effectiveness, (b) improved governance for enhanced financial management and operational and commercial efficiency in stakeholder agencies, (c) assessment of financial intermediation capacity in KUIDFC and preparation of a future road map, and (d) oversight of economic and service standard regulations in ULB operations.

With this policy framework, the state government undertook, in February 2020, a big implementation step by instituting seven policy guidelines in four areas for improved water supply and sanitation services, including the water service charters and water safety plans in Karnataka (Box 2):

(i) Urban water management: (a) guidelines for promoting urban watershed management and (b) guidelines for developing water safety plans (WSPs).

(ii) Water accounting: (a) guidelines for regularizing unauthorized connections and (b) a monitoring and assessment framework for NRW.

(iii) Demand management: (a) a model for volumetric tariff determination and (b) guidelines for drawing up a strategy plan to manage urban drinking water demand and establishing a policy on public stand posts.

(iv) Improved service standards: water service charters. 


\section{Box 2: Water Service Charters and Water Safety Plans in Karnataka}

\section{Why Are Water Service Charters Important?}

A water service charter is an organized set of stipulations and protocols for water services that defines the rights and privileges of service consumers. It establishes a framework to safeguard the safe and reliable management of the complete range of water services, including reliable drinking water supply, wastewater treatment and disposal, and stormwater drainage.

Once implemented by the service provider, often an urban local body, the charter becomes both a commitment and a liability. It defines the obligations of the service provider and sets its standards for service delivery, customer service, maintenance and repair, and performance monitoring, while periodically updating and upgrading service standards.

While most water utilities in India have instituted citizen or customer service charters, a unique feature of the Karnataka water service charter is that it does not limit its commitments to obligations related to customer services, but includes all obligations of the water utility to guarantee service quality, standards, and maintenance and repair for delivery of reliable services. It also integrates compliance performance monitoring into national service benchmarks.

\section{How Water Safety Plan Guidelines Work in Karnataka}

A water safety plan (WSP) develops risk management system to ensure safe drinking water supply. It covers all activities in the water supply chain, from the catchment to the consumer.

WSPs are relatively new to India, especially in the urban water sector. Except in a few cities that instituted city-specific WSPs, the implementation of plans remains at the nascent stage. In the Karnataka Integrated Urban Water Management Investment Program, city-specific WSPs are being implemented with contractors in the framework of urban local body incentive funds. Applying and maintaining WSPs ensure that operators assume responsibility for safe water supply to consumers.

\section{Key Feature: Institutional Transformation Implemented with Urban Local Body Incentive Funds}

With state policy in place, what guarantees the effective implementation by ULBs? The ULB incentive funds (UIFs) are an innovative intervention by the state government. A UIF motivates project ULBs to implement reforms and become efficient and responsive municipal service providers. City-specific water service charters and WSPs are embedded in the framework of UIF implementation.

A UIF is implemented in three stages, with eligible expenditure under these activities and incentives allocated upon successful completion. KUIDFC will release incentive payments to ULBs after a third party verifies the completion of reforms at each stage.

(i) Financial and commercial capacity enhanced (stage 1). ULBs are encouraged to update water consumer information in an IT database, regularize illegal connections, and explore options to subsidize connections for the urban poor. 
(ii) Technical capacity enhanced for improved service (stage 2). Each project ULB develops a volumetric water tariff structure for different types of use, adopts a subsidized rate for the poor, rolls out the computerized management of water billing and collection accounts, achieves 100\% sewerage connection, obtains the approval by elected ULB councils of the water service charter, and develops an IT-based asset management system.

(iii) Sustainable management capacity enhanced (stage 3). This final stage facilitates ULB development of a system to continuously assess its water balance, NRW, and revenue and expense balance; process regular revisions of water tariffs; assess the condition of its water utility assets; prepare a city-level water and sanitation masterplan for the urban watershed, including a WSP; and build capacity of ULB managers.

The project 1 towns of Byadagi, Davangere, Harihar, and Ranebennur have completed all stage 1 activities and have begun implementing stage 2 . The project 2 towns of Kundapura, Mangaluru, Puttur, and Udupi have passed their council resolutions and will start implementing stage 1 by the third quarter of 2020 . All stages are scheduled for completion by 2023.

\section{Key Feature: Institutional Transformation through Information Technology Module Development to Implement Urban Local Body Reforms}

To advance the implementation of the UIF, the development of enhanced IT modules help project ULBs operate water services sustainably. The modules are designed to improve information managementwith enhanced data capture, analysis, benchmarking, dissemination, and monitoring - and management decisions on water services. These modules are numbered from 1 to 4 , with IT module 1 (IT1) managing the customer database including billing; IT module 2 (IT2) ring-fencing water and wastewater service accounts to enable ULBs to assess income, revenue, profits, and loss; IT module 3 (IT3) providing a webbased management information system for water and wastewater services with a built-in tool for assessing NRW accounting; and IT module 4 (IT4) providing a GIS-enabled enterprise asset management system to support management planning. The Korea Water Resources Corporation (or K-water), a government agency for water resources development and water supply provision in the Republic of Korea, supported KUIDFC as it prepared the functional requirements for these IT modules.

The integrated modules enable ULBs to make timely management and planning decisions through the digitalization of property-linked customer databases, GIS mapping, supervisory control and data acquisition, and asset management. Information collected from the four modules is used to monitor various technical parameters and the financial performance of water and sewerage services; it is also used to generate reports with performance indicators for flow, pressure, water quality, and the quality of sewage treatment plant effluents, as well as other factors. IT1 and IT2 were rolled out to 18 towns, including the towns of project 1 and project 2, in January 2020. Byadagi in project 1 and Kundapura in project 2 were selected for fast-tracking the complete operationalization of IT1 (Box 3). The draft functional requirements of IT3 and IT4 are currently being finalized for rollout in project 1 towns by early 2021. These IT modules support ULBs to implement the transformational reform as designed in a UIF (Table 7). 


\section{Box 3: Functionality of the Information Technology Modules 1 and 2}

Among the information technology (IT) modules developed to assist urban local bodies (ULBs) implement the transformative institutional reform stipulated in the ULB incentive funds are the following:

- IT module 1 (IT1) enables ULBs to provide an integrated solution covering their consumers database, procedure for availing water connections and reconnections, water bill generation in both flat and volumetric modes, and bill issuance and payments including short message service (SMS) notification facility. IT1 also includes a system for identifying defaulters and illegal connections, integrating with payment gateways, and consumer complaint redressal.

- IT module 2 (IT2) has been developed for the ring-fenced accounting of water and wastewater services, covering expenditure, revenue, billing collection, details of arrears, and current year demand and collection. This enables the ULBs to assess the income, revenue, profitability or loss, and subsequently aid in delineating the financial budget, particularly on water and wastewater services. IT2 also allows integration with ULB's accounting system.

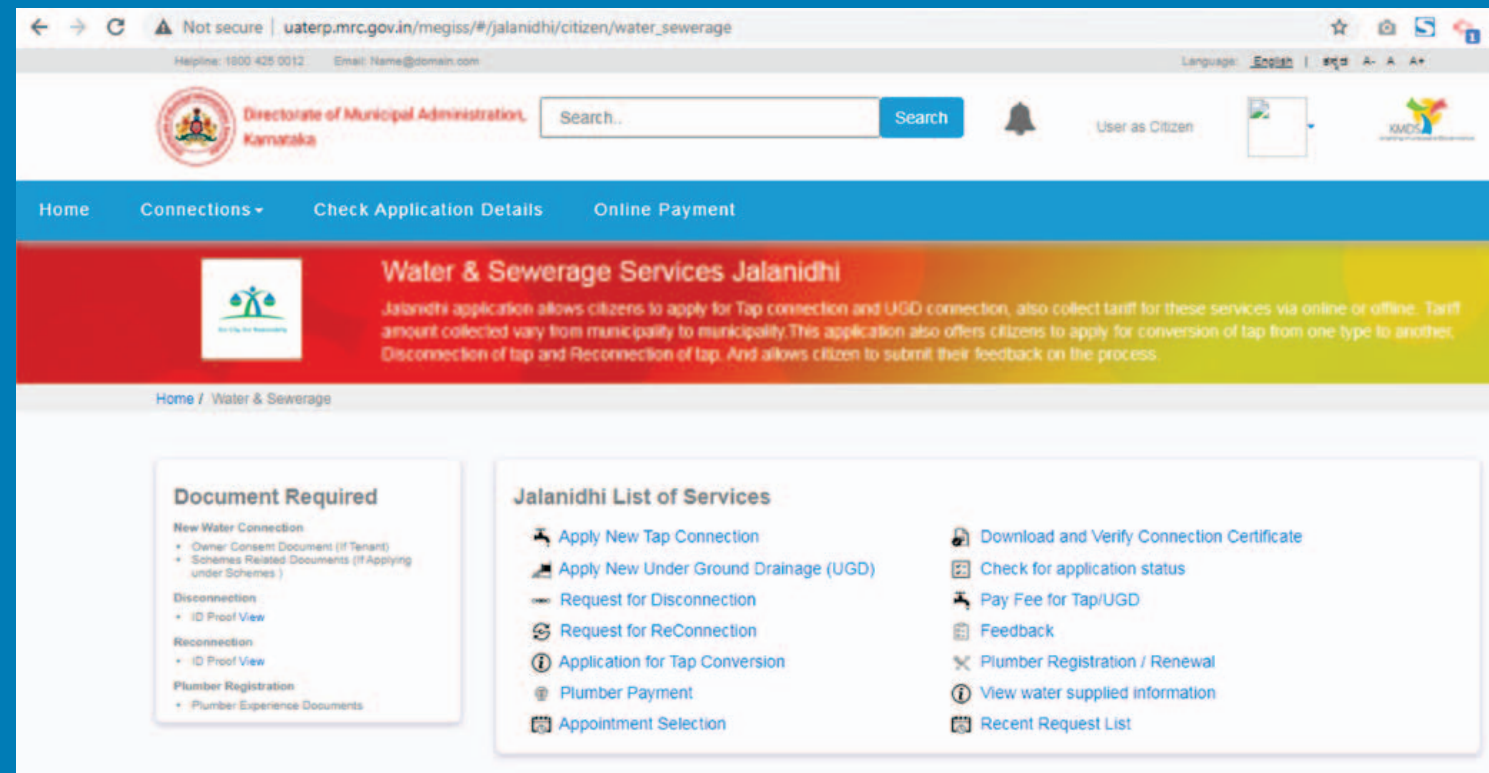

Sample IT1 module. A list of the water and sewerage services provisioned in Jalanidhi application is shown in this master screen (photo by ADB). 
Table 7: Activities of the Urban Local Body Incentive Funds Supported by the Information Technology Modules

\begin{tabular}{|c|c|c|c|}
\hline Reform & Activity & Stage & $\begin{array}{l}\text { Supporting } \\
\text { IT Module }\end{array}$ \\
\hline \multirow{4}{*}{$\begin{array}{l}\text { Update water } \\
\text { consumer } \\
\text { information in } \\
\text { a computerized } \\
\text { database }\end{array}$} & $\begin{array}{l}\text { - ULB resolution to be passed for computerizing water consumer } \\
\text { information and legalizing illegal connections }\end{array}$ & 1 & \\
\hline & $\begin{array}{l}\text { - Transferring existing Demand Collection and Balance registered } \\
\text { connections to a computerized database and verifying them on the ground }\end{array}$ & 1 & 1 \\
\hline & $\begin{array}{l}\text { - Procedure set to convert illegal water and sewer connections into } \\
\text { legal connections }\end{array}$ & 1 & 1 \\
\hline & - Standard procedure set for new water and sewer connections & 1 & 1 \\
\hline \multirow{4}{*}{$\begin{array}{l}\text { Achieve } \\
\text { metered water } \\
\text { supply }\end{array}$} & - ULB resolution for water metering in conjunction with $24 / 7$ water services & 2 & \\
\hline & $\begin{array}{l}\text { - Standpost assessment and feasible options for water services to the } \\
\text { urban poor }\end{array}$ & 1 & 1 \\
\hline & - Achievement of $100 \%$ metered water supply connections & 3 & 1 and 2 \\
\hline & - System made available for continuous nonrevenue water assessment & 3 & 2 and 3 \\
\hline \multirow{3}{*}{$\begin{array}{l}\text { Adopt } \\
\text { volumetric } \\
\text { tariffs for } 24 / 7 \\
\text { water supply } \\
\text { services }\end{array}$} & - ULB resolution for approval of proposed volumetric tariff structure & 2 & \\
\hline & $\begin{array}{l}\text { - Completion of applicable volumetric tariff structure for different types } \\
\text { of users in ULBs }\end{array}$ & 2 & 1 and 2 \\
\hline & - Billing and payment procedures finalized and communicated to customers & 1 & 1 \\
\hline \multirow{4}{*}{$\begin{array}{l}\text { Attain efficient } \\
\text { collection of } \\
\text { water tariff } \\
\text { based on actual } \\
\text { demand }\end{array}$} & $\begin{array}{l}\text { - Flat tariff water bill collection in a computerized database to be recorded } \\
\text { monthly }\end{array}$ & 1 & 1 and 2 \\
\hline & $\begin{array}{l}\text { - Volumetric tariff water bill collection in a computerized database to be } \\
\text { recorded monthly }\end{array}$ & 3 & 1 and 2 \\
\hline & $\begin{array}{l}\text { - Sanitation tariff bill collection in a computerized database to be recorded } \\
\text { monthly }\end{array}$ & 3 & 1 and 2 \\
\hline & - Implementation of online payment facilities for all consumers & 2 & 2 \\
\hline \multirow{3}{*}{$\begin{array}{l}\text { Apply ring- } \\
\text { fenced IT-based } \\
\text { accounting for } \\
\text { water supply } \\
\text { and sanitation } \\
\text { services }\end{array}$} & $\begin{array}{l}\text { - Rollout of fully computerized management of water billing and collection } \\
\text { accounts }\end{array}$ & 2 & 2 \\
\hline & $\begin{array}{l}\text { - Rollout of fully computerized management of sewer connection billing and } \\
\text { collection accounts }\end{array}$ & 2 & 2 \\
\hline & $\begin{array}{l}\text { - Monthly statement issued in fund-based double-entry accrual accounting } \\
\text { system, excluding water and wastewater services issued to Karnataka } \\
\text { Urban Infrastructure Development and Finance Corporation }\end{array}$ & 2 & 2 \\
\hline \multirow{3}{*}{$\begin{array}{l}\text { Institute process } \\
\text { for periodic } \\
\text { revision of water } \\
\text { and sanitation } \\
\text { tariffs }\end{array}$} & $\begin{array}{l}\text { - Water and wastewater service expenses published on ULB website every } \\
6 \text { months }\end{array}$ & 3 & 2 and 3 \\
\hline & $\begin{array}{l}\text { - Shortfall indicated between operation and maintenance expenses and } \\
\text { payment received for water services }\end{array}$ & 3 & 3 \\
\hline & - Process to revise water tariffs in proportion to service expense & 3 & 3 \\
\hline
\end{tabular}


Table 7: Continued

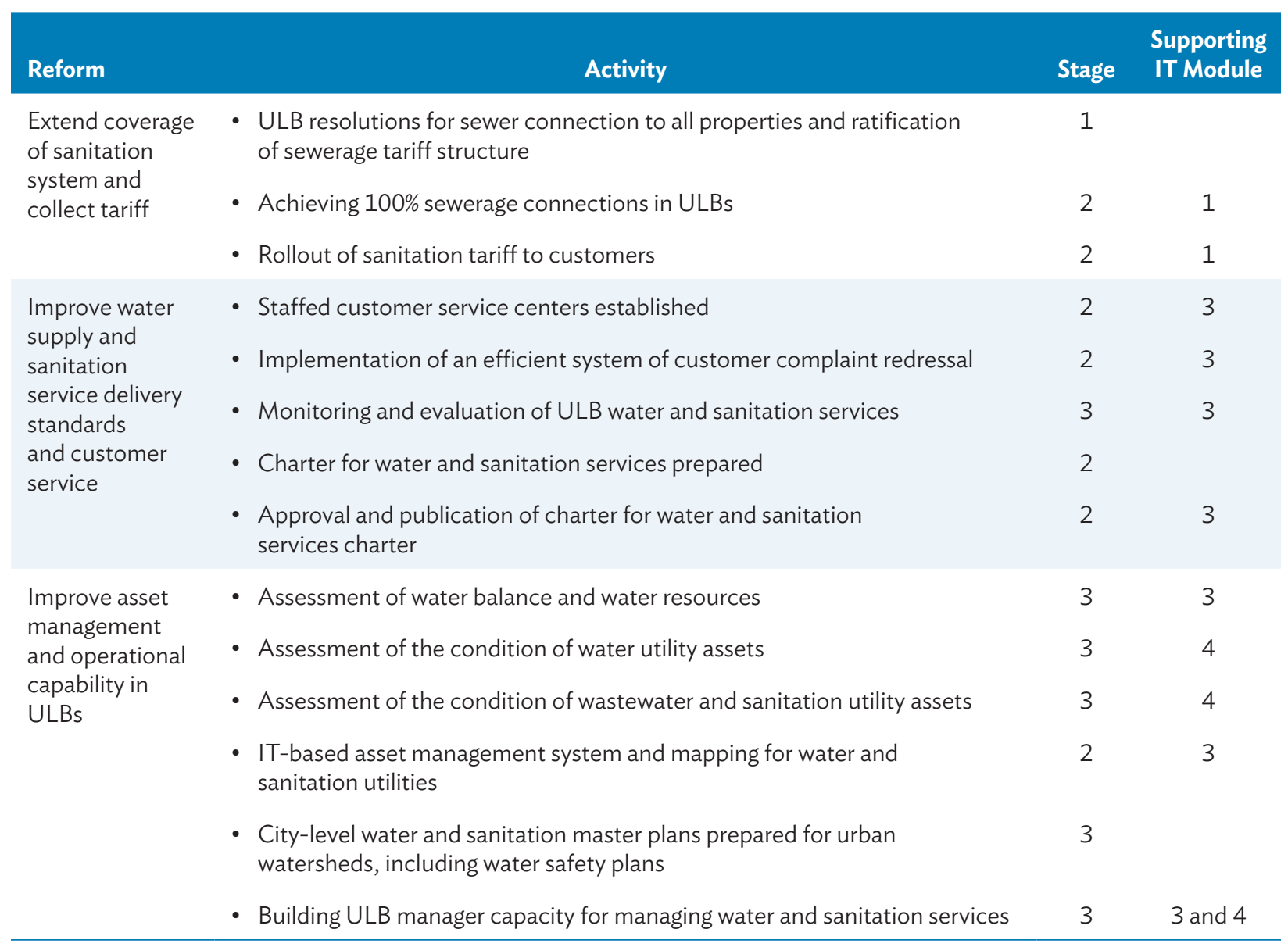

IT = information technology, ULB = urban local body.

Source: Karnataka Urban Infrastructure Development and Finance Corporation.

\section{The Karnataka Integrated Urban Water Management Investment Program Model}

Following the accomplishment in Ilkal town, the KIUWMIP is developed with enhanced service requirements: 24/7 water supply, 100\% coverage, house service connections, low NRW achieved through DMAs, and the PBCOC model. In addition to such arrangement, the KIUWMIP implements transformative policy and institutional reform that includes the development of statewide policy guidelines, UIFs, and their IT modules. All of these components were all designed to reflect the experience gained from prior projects. The KIUWMIP model is an enhanced Ilkal model, as it adds new features to ensure effective mechanisms for improving utility O\&M (Figure 1). 

Figure 1: How the Ilkal Model Evolved into the Karnataka Integrated
Urban Water Management Investment Program Model

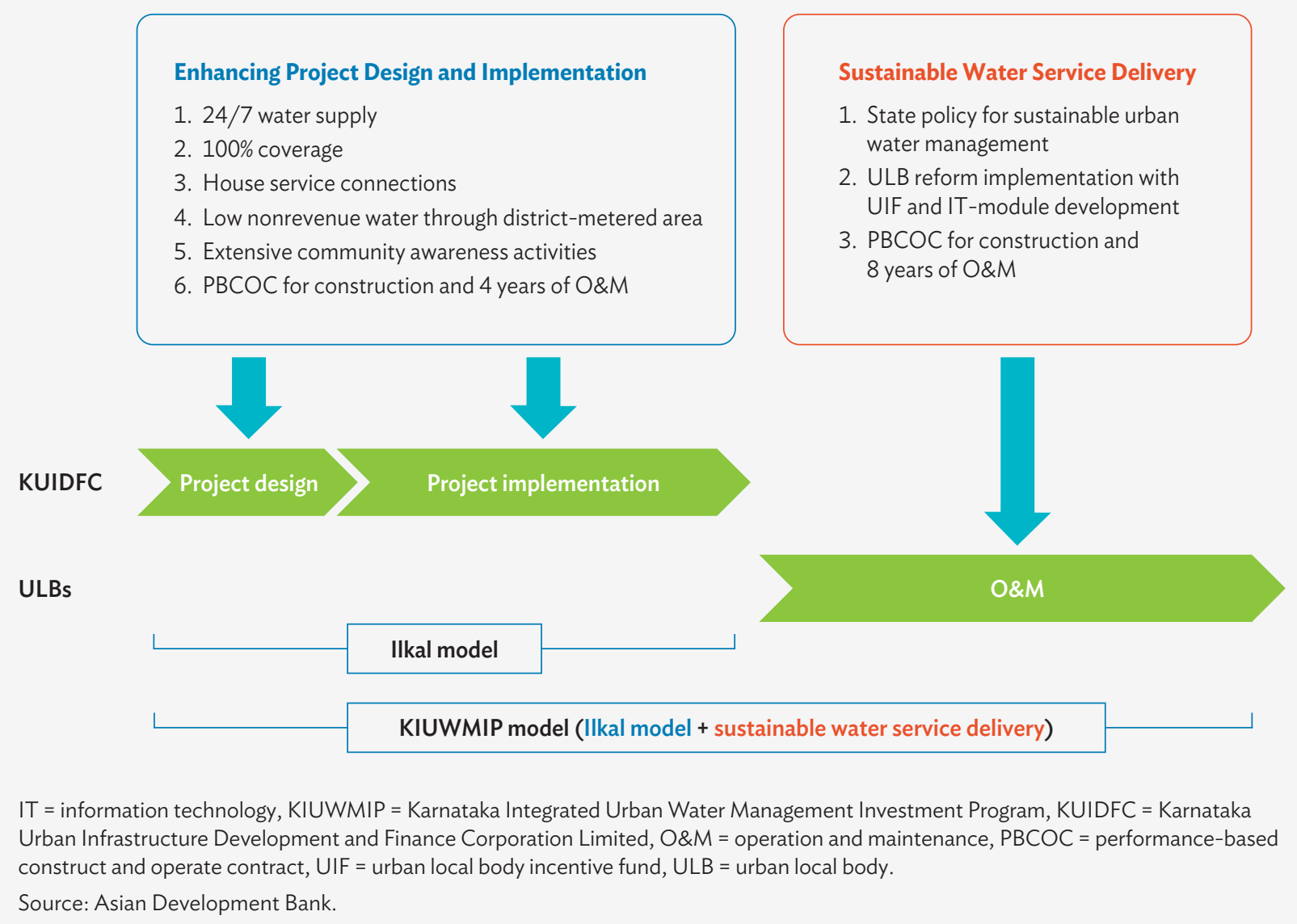

The KIUWMIP model aims to create robust virtuous cycles for sustainable water services (Figure 2). The upward spiral starts with the following:

(i) the development of high-quality infrastructure able to provide $24 / 7$ water supply with $100 \%$ coverage in direct connections to houses, less nonrevenue water, and asset management and operation monitoring technologies;

(ii) improved water services achieved through incentives for operators under a PBCOC, utility commitment expressed in water service charters and WSPs, and enhanced utility management through UIF and IT module development;

(iii) community awareness and participatory activities to improve people's understanding of project benefits; and

(iv) adequate financial sources guaranteed by lower costs and higher user charges achieved through improved tariff collection efficiency and tariff increases, ultimately achieving full cost recovery for O\&M. 
Figure 2: Virtuous Cycle of the Karnataka Integrated Urban Water Management Investment Program Model for Sustainable Water Services

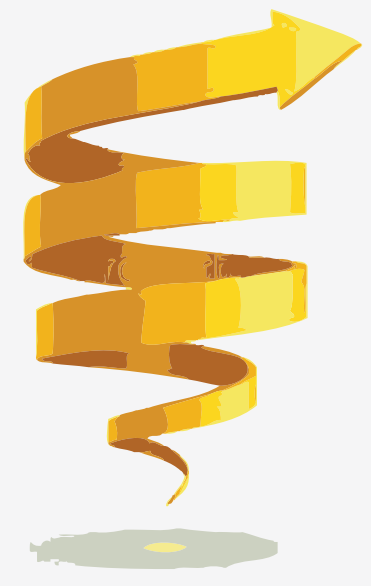

IT = information technology, KIUWMIP = Karnataka Integrated Urban Water Management Investment Program, O\&M = operation and maintenance, $\mathrm{PBCOC}=$ performance-based construct and operate contract, UIF = urban local body incentive fund.

Source: Asian Development Bank.

The key success factor of this KIUWMIP model is its ability to incentivize good performance from contractors and smoothen the transition from construction to O\&M. The PBCOC model heavily stresses contractor performance. Qualification criteria should be carefully established to select experienced contractors who have enough capacity for design validation and the long-term O\&M of water supply schemes. Employer should build confidence in potential bidders that they will receive service payments from local municipalities by opening escrow accounts, where water tariffs and other funds to pay O\&M expenses are deposited into. Moreover, ULBs should be technically and institutionally ready to take over the infrastructure assets before they are commissioned. The KIUWMIP model aims to ensure sustainable O\&M for 8 years by enhancing the institutional capacity of the ULBs through IT module development and UIF implementation; the adequate handover support to be provided by PBCOC operators to ULBs; and the constant monitoring and technical and institutional support from KUIDFC and district urban development units. Any gaps in ULB capacity should be assessed and duly filled. 


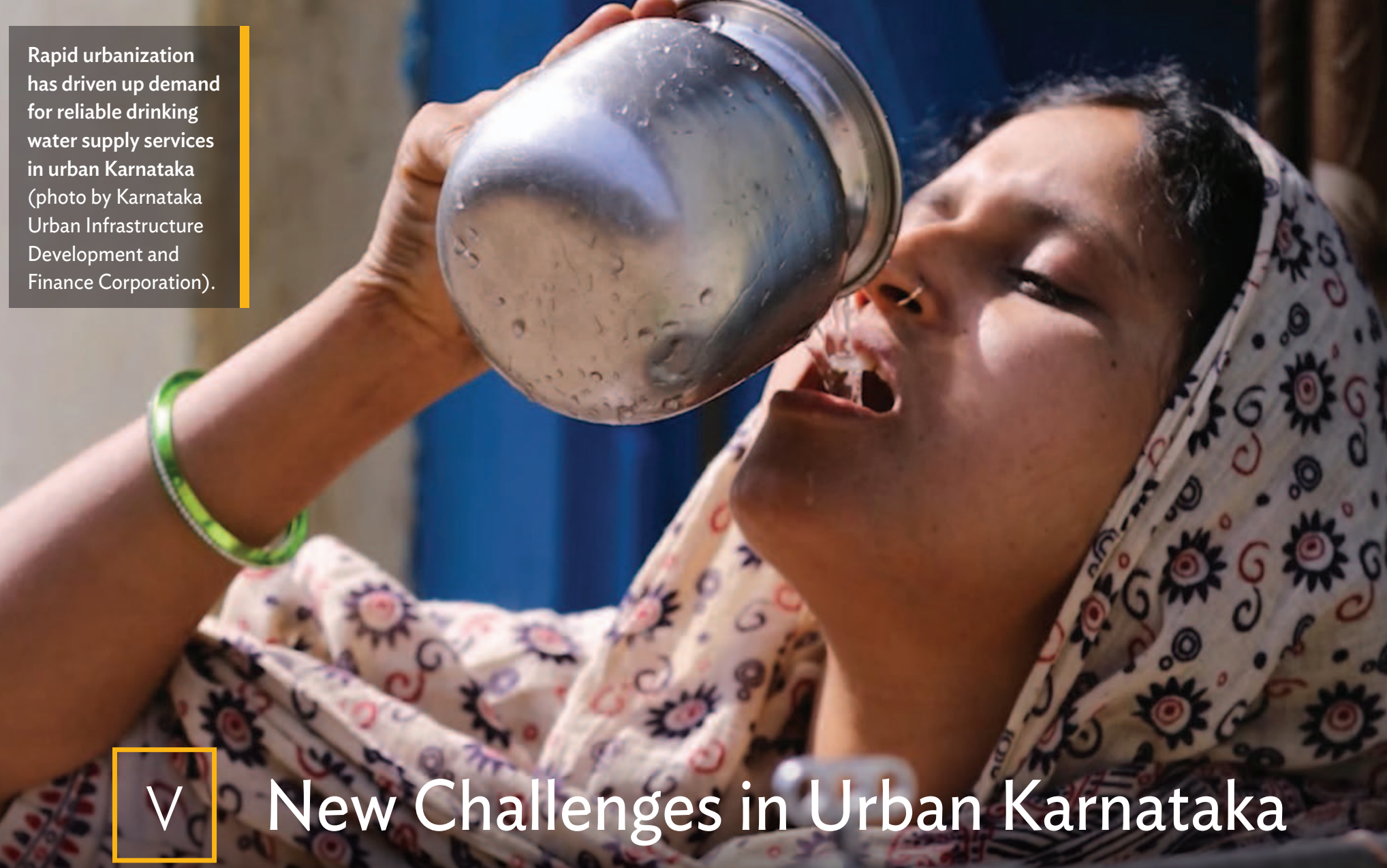

\section{A. Climate Change and Water Conservation to Counter Future Drought}

In the drought-prone State of Karnataka, the effective management of water resources will be a prime challenge for future urban and economic development. Climate stress can affect systems of potable water supply and sanitation. Drought is especially problematic for water supply systems reliant on surface water sources, which are sensitive to temperature increases, temporal and spatial variations in rainfall, and changes in cumulative precipitation. Sewerage systems are also sensitive to climate change because their efficient functioning is directly linked to sustainable and climate-resilient water supply systems.

Projects located in drought-prone areas should include components to strengthen climate resilience, as designed into the KIUWMIP. Projects can (i) use only sustainable surface water sources as determined through a sustainability assessment, (ii) reduce NRW through enhanced distribution systems using DMAs, and (iii) raise awareness among beneficiaries to promote demand management.

Further, the KIUWMIP supports the state government's implementation of climate-resilient policy actions at the ULB level: (i) promoting rainwater harvesting in project ULBs; (ii) incentivizing the use of treated wastewater in industry, agriculture, and horticulture; and (iii) institutionalizing rigorous water quality assurance and audit norms. Preliminary findings of these ongoing interventions show that policy implementation at the municipality level requires adequate consultations with stakeholders, effective enforcement or incentive mechanisms or a business model with clear roles and responsibilities for government departments, and awareness raising and capacity building in local municipalities. 
Strengthening climate resilience needs a holistic approach that features institutional and technical support. The implementation of a rainwater harvesting policy requires extensive technical support for ULBs to identify their gaps and solutions in consultation with stakeholders. Collaboration with the Mangalore SEZ at the Kavoor sewage treatment plant (Box 1 ) demonstrates good practice for a win-win public-private business model that reuses treated wastewater. City-specific water charters and WSPs can be instituted, as in the UIF of the KIUWMIP, to help ULBs and operators assure high-quality water services through a PBCOC.

\section{B. Business Process Reengineering to Meet Growing Demand for Urban Services}

In continuing efforts to improve project design and O\&M, which areas can be enhanced to deliver higher-quality urban services? In Karnataka, 37\% of the state's 61.1 million residents live in urban areas. Rapid urbanization and resulting sharp increases in city populations have driven up demand for urban infrastructure and services. While the state government prioritizes urban development, the business processes of urban projects can be reengineered at each stage of the project cycle.

Project preparation. High demand for new urban projects requires efficient project preparation mechanisms, such as project development funds for project design. Such funds can be pooled using grants from the state government. Alternatively, funding from development partners, such as through the new ADB financing modality called project readiness financing, can facilitate project preparation. A project readiness financing loan covers project preparation and design for investments expected to be financed under ensuing ADB financing. ${ }^{3}$

Project implementation. Externally aided urban projects in Karnataka are implemented by KUIDFC. The KIUWMIP has established project implementation units in each town — an arrangement suitable for the currently limited implementation capacity of ULBs. However, in the medium and long term, the ULBs should be empowered to implement their own projects, as the resulting assets will eventually be transferred to them. The gradual transfer of implementation functions can be considered while assessing and enhancing the technical and managerial capacity of the ULBs. Considering limited human resources in the ULBs, a first step may be to enhance the capacity of KUIDFC and/or district urban development units to support the ULBs before full implementation is delegated to them.

Financing. More funds are required to meet the growing demand for urban infrastructure. With its good track record of 25 years, KUIDFC will continue to mobilize external financial resources for urban Karnataka. To further enhance external finance, KUIDFC can take a leading role in promoting innovative multisector programs that extend beyond the mandate of any single line department. For example, KUIDFC may develop a comprehensive urban sewerage and drainage program.

3 Activities supported by project readiness financing include (i) upstream project pipeline development, sector studies, and investment plans; (ii) feasibility studies and due diligence assessments for ensuing project(s); (iii) detailed engineering designs; and (iv) project pre-implementation capacity building in executing agencies linked to a project or the pipeline of ensuing projects. 
The program should promote provision of equitable and safe sanitation services for all households through house service connections, while avoiding sewage directly entering drains and joining water bodies in the absence of sewage treatment. It can also reduce the flood risks through an integrated approach with structural measures-e.g., gray infrastructure (i.e., construction of stormwater systems) and green infrastructure (i.e., nature-based solution) - and nonstructural measures-e.g., land use planning, awareness campaigns, early flood warning system, and solid and liquid waste management. In areas where water sources are scarce during the summer season, the ULBs can enhance water conservation through rejuvenation of water bodies; enhanced ground infiltration; and harvesting of wastewater, rainwater, and/or stormwater. KUIDFC is of great advantage to undertake such a holistic approach as they have rich urban experiences in multidimensional sector development, substantial achievements in policy and institutional reforms, and strong coordination capacity within the state. KUIDFC can also explore fund mobilization from the private sector, municipalities, or market. A public-private partnership can be further expanded between the ULBs and industries to reuse the wastewater treated at sewage treatment plants, as seen in Mangaluru. The ULBs can promote municipal resource mobilization through improved property tax collection in line with the recommendations of the Fifteenth Finance Commission of the Government of India. KUIDFC can consider enhancing its own capacity for fund mobilization and management in order to transform itself into a financial intermediary to support urban development in Karnataka. In the medium term, market funding through, e.g., municipal bonds, may supplement public investment, but this requires a risk management framework to address interest and maturity mismatches between assets and liabilities and resulting financial risks.

Operation and maintenance. As discussed above, an effective mechanism for O\&M is being established. The state government and KUIDFC can expedite reform in the ULBs through UIFs and IT modules, and scale up this KIUWMIP model across the state. The state government may also hold stakeholder consultations on an oversight framework for drinking water, sanitation, and stormwater management. Reform may start with an advisory body to assess the ULB service standards and provide technical support. In the longer term, this body can evolve into an independent regulatory body, such as a state water council, to ensure sustainable, reliable, and equitable water management in line with a water service charter.

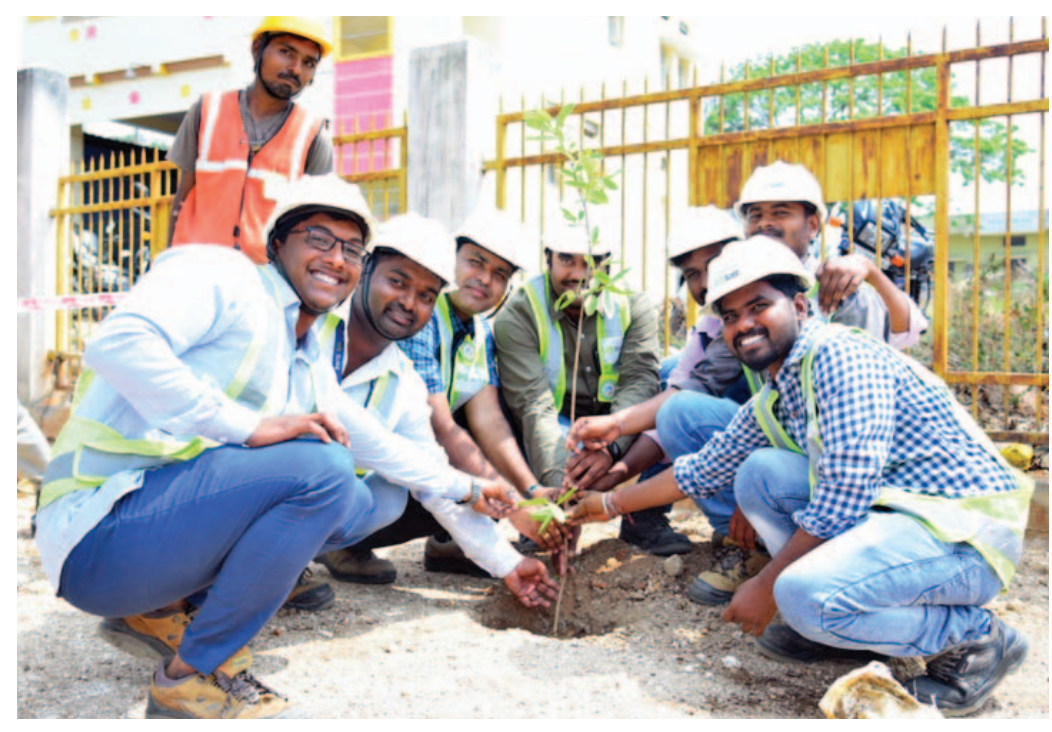

$\checkmark$ Investment for green future.

Urban Karnataka is growing while restoring the nature to meet the socioeconomic and environmental needs (photo by Karnataka Urban Infrastructure Development and Finance Corporation Limited). 

Simple project scope minimizes problems in implementation. Complex projects-those that envision a wide range of outputs across multiple sectors in many towns that are geographically remote from one another-stretch the design, monitoring, and implementation capacity of executing agencies, causing design failure, poor supervision, coordination problems, and implementation delays. In urban Karnataka, following the experiences of prior projects, the KIUWMIP avoids overly complex project scope, limiting interventions to only seven towns in two tranches. This simplified arrangement helps KUIDFC and ADB strengthen project monitoring in close coordination with the ULBs. Project 2 of the KIUWMIP implemented project preparation proactively, with all contracts signed and more than $20 \%$ of disbursement achieved within 1 year after the loan went into effect. The project implementation is on good track despite the COVID-19 pandemic in the first half of 2020. During project preparation, capacity should be assessed to find the right balance between project complexity and implementation capacity. Innovative components should be included in proportion to the executing agency's capacity. Rather than putting everything in one project, a phased program should be developed with several focused interventions over a longer time frame.

Community awareness is an essential component of a virtuous cycle. In the KUDCEMP and the NKUSIP, community components built community awareness of hygiene and sanitation improvements delivered by the projects, engendering high community ownership. Under the NKUSIP, the awareness programs were conducted with support from an apex NGO at the center and NGOs implementing in each town gender action and community development plans. Following the experience of the KUDCEMP, all project towns of project 2 of the KIUWMIP hold extensive consultation meetings in every ward to address people's queries and concerns. These initiatives demonstrated that social components are as important as technical components to project sustainability. When services are of high quality, and customer services such as complaint registration are reliable, people come to understand the importance of sustainable service provision and support cost recovery, thereby adding lift to the upward spiral.

Institutions matter. The 25-year partnership in urban Karnataka is a story of institutional transformation. It started with support for capacity building in KUIDFC, launched municipal reforms across the state, generated the Ilkal model with a PBCOC, and further enhanced institutional arrangements through the KIUWMIP model with state policy guidelines, UIFs, and IT modules. As demand continues to grow, KUIDFC faces new challenges to reengineer its business process. Establishing project development funds for project design could facilitate the efficient project preparation for growing requirements. The gradual transfer of implementation functions from KUIDFC to the ULBs can be explored while enhancing ULB's technical and managerial capacity. KUIDFC can take a leading role in promoting innovative multisector programs, with the finance from external development partners, while exploring fund mobilization from the private sector, municipalities, or market in the medium term. KUIDFC has the potential to transform itself into a financial intermediary and help strengthen urban development in Karnataka over a longer time horizon. The state government may further consider establishing a technical advisory body to assess ULB water service standards and provide technical support. It may eventually evolve into an independent regulatory body to ensure sustainable, reliable, and equitable water management. Continuing institutional transformation and business process reengineering of project interventions helps realize sustainable water service delivery at larger scale. 
A virtuous cycle cannot be built in a day. Ensuring an upward spiral for better water services is a major challenge for any city or state. This publication shows Karnataka to be a model for technical, institutional, and social interventions able to supply sustainable, high-quality urban water services. No shortcuts exist to sustainable service delivery. The interventions have evolved over decades through constant interactions between the Government of Karnataka, KUIDFC, and ADB. The unrelenting efforts include sector analysis, capacity building, policy dialogue, and project evaluation, which resulted in reflection of lessons learned in prior program(s) and innovation of new program designs. ADB has engaged in institutional support for KUIDFC in the early stages, policy dialogues to support municipal reforms in the state under the KUDCEMP, technical support for participatory project planning of the NKUSIP, and project preparation based on an IWRM approach for the KIUWMIP. The common understanding of the need to scale up good practices and broader institutional changes to promote sustainable O\&M was a driving factor to moving from the Ilkal model (pilot-based and localized interventions) to the KIUWMIP model (full-scale and broader institutional changes). It took a decade to develop the Ilkal model, and another decade for the KIUWMIP model-both of which still require fine-tuning and upgrading with business process reengineering at each stage of project cycle, from project preparation to O\&M. However, this long partnership shows what works and what does not work on the ground, indicating the way forward. Development partners should learn from past experience, adopt a programmatic approach, and continue to reach out to beneficiary communities to ensure sustainable service delivery. 


\section{Bibliography}

\section{Section I. Karnataka Urban Infrastructure Development Project}

Asian Development Bank (ADB). 1993. Technical Assistance to India for Urban Infrastructure Development Project. Manila.

_. 1994. Technical Assistance to India for Capacity Building for Improved Infrastructure Development in Selected Municipalities in Karnataka State. Manila.

—. 1995a. Report and Recommendation of the President to the Board of Directors on Two Proposed Loans and Technical Assistance to the Republic of India and the Housing Development Finance Corporation Limited for the Karnataka Urban Infrastructure Development Project. Manila.

—. 1995b. Technical Assistance to India for Institutional Strengthening of Karnataka Urban Infrastructure Development and Finance Corporation. Manila.

—. 1995c. Technical Assistance to India for Resource Mobilization Study for Local Governments in Karnataka. Manila.

—. 2006a. Completion Report: Karnataka Urban Infrastructure Development Project. Manila.

\section{Section II. Karnataka Urban Development and Coastal Environmental Management Project}

ADB. 1997. Proposed Technical Assistance for Karnataka Coastal Environmental Management and Urban Development Project. Manila.

1999. Report and Recommendation of the President to the Board of Directors on a Proposed Loan for the India for the Karnataka Urban Development and Coastal Environmental Management Project. Manila.

_. 2012. Completion Report: Karnataka Urban Development and Coastal Environmental Management Project. Manila.

_. 2017a. Asian Development Blog on Mangalore Shows the Way on Wastewater Management in India. June.

Independent Evaluation Department. 2016. Performance Evaluation Report: Karnataka Urban Development and Coastal Environmental Management Project. Manila: ADB.

\section{Section III. North Karnataka Urban Sector Investment Program}

ADB. 2006b. Report and Recommendation of the President to the Board of Directors: Proposed Multitranche

Financing Facility to India for the North Karnataka Urban Sector Investment Program. Manila.

_. 2006c. Technical Assistance Cluster to India for Project Processing and Capacity Development. Manila.

_. 2017b. 24/7 Normalized Water Supply Through Innovative Public-Private Partnership Case Study from Ilkal Town, Karnataka, India. Manila.

_. 2018. Periodic Financing Request Report: Karnataka Integrated Urban Water Management Investment Program (Tranche 2). Manila.

\section{Section IV. Karnataka Integrated Urban Water Management Investment Program}

ADB. 2014. Report and Recommendation of the President to the Board of Directors: Proposed Multitranche Financing

Facility to India for the Karnataka Integrated Urban Water Management Investment Program. Manila.

World Bank. 2019. Reform and Finance for the Urban Water Supply and Sanitation Sector. Washington, DC. 


\section{Years of Partnership with Karnataka Evolving Model for Sustainable Urban Water Service Delivery}

The year 2020 marks 25 years of partnership between the Asian Development Bank (ADB) and the Government of Karnataka. From the approval in 1995 of the Karnataka Urban Infrastructure Development Project, ADB's first urban sector loan in India, the bank's interventions have expanded through three consecutive urban sector programs across the state. These interventions have evolved over time, reflecting lessons learned and innovations in project design, scope, and operation and maintenance arrangements to

improve urban water services. The constructive partnership marks an institutional transformation, adopting a programmatic and inclusive approach to ensure sustainable service delivery in urban Karnataka.

\section{About the Asian Development Bank}

ADB is committed to achieving a prosperous, inclusive, resilient, and sustainable Asia and the Pacific, while sustaining its efforts to eradicate extreme poverty. Established in 1966, it is owned by 68 members -49 from the region. Its main instruments for helping its developing member countries are policy dialogue, loans, equity investments, guarantees, grants, and technical assistance. 